NBER WORKING PAPER SERIES

\title{
THE POTATO'S CONTRIBUTION TO POPULATION AND URBANIZATION: EVIDENCE FROM AN HISTORICAL EXPERIMENT
}

\author{
Nathan Nunn \\ Nancy Qian \\ Working Paper 15157 \\ http://www.nber.org/papers/w15157 \\ NATIONAL BUREAU OF ECONOMIC RESEARCH \\ 1050 Massachusetts Avenue \\ Cambridge, MA 02138 \\ July 2009
}

We thank David Canning, Greg Clark, Angus Deaton, Azim Essaji, Andrew Foster, Oded Galor, Claudia Goldin, Larry Katz, Wolfgang Keller, Joel Mokyr, Jean-Laurent Rosenthal, Yona Rubinstein, Andrei Shleifer, Peter Temin, and David Weil for valuable feedback and discussions. We also thank seminar participants at Bocconi University, Boston University, Brown University, Harvard University, MIT, Ohio State University, Princeton University, Tufts University, University of Chicago Booth School of Business, BREAD, CEA Annual Meetings, ISNIE Annual Conference, and NEUDC Annual Conference. We thank Sayon Deb for excellent research assistance. The views expressed herein are those of the author(s) and do not necessarily reflect the views of the National Bureau of Economic Research.

NBER working papers are circulated for discussion and comment purposes. They have not been peerreviewed or been subject to the review by the NBER Board of Directors that accompanies official NBER publications.

(C) 2009 by Nathan Nunn and Nancy Qian. All rights reserved. Short sections of text, not to exceed two paragraphs, may be quoted without explicit permission provided that full credit, including $\odot$ notice, is given to the source. 
The Potato's Contribution to Population and Urbanization: Evidence from an Historical Experiment Nathan Nunn and Nancy Qian

NBER Working Paper No. 15157

July 2009

JEL No. J1,N1,N5,O13,O14

\title{
$\underline{\text { ABSTRACT }}$
}

We exploit regional variation in suitability for cultivating potatoes, together with time variation arising from their introduction to the Old World from the Americas, to estimate the impact of potatoes on Old World population and urbanization. Our results show that the introduction of the potato was responsible for a significant portion of the increase in population and urbanization observed during the 18th and 19th centuries.

\author{
Nathan Nunn \\ Department of Economics \\ Harvard University \\ 1805 Cambridge Street \\ Cambridge, MA 02138 \\ and NBER \\ nnunn@fas.harvard.edu \\ Nancy Qian \\ Department of Economics \\ Yale University \\ 27 Hillhouse Avenue \\ New Haven, CT 06520-8269 \\ and NBER \\ nancy.qian@yale.edu
}




\section{Introduction}

Between 1000 and $1900 \mathrm{AD}$, world population grew from under 300 million to 1.6 billion, and the share of population living in urban areas more than quadrupled, increasing from two to over nine percent. As shown in Figure 1, this increase occurred almost entirely in the latter two or three centuries of this period. ${ }^{1}$ The determinants of these phenomena have been the subject of much interest to economists, demographers and historians. ${ }^{2}$ Population increase can be the result of either an increase in fertility and/or a decline in mortality. The latter was particularly important after 1820, when fertility began to decline (Maddison, 1991, p. 241).

The seminal empirical studies by Fogel $(1984,1994,2004)$ and McKeown (1976) argue that the main contributing factor to the decline in mortality, and the resulting increase in life expectancy, was improved nutrition. ${ }^{3}$ Fogel (2004) shows that there was an enormous increase in caloric intake after the middle of the eighteenth century, measured both directly, from agricultural output and diary surveys, and indirectly through changes in adult height. Between the middle of the eighteenth century and today, for example, caloric intake per person increased by more than thirty percent, and heights in most of Europe increased by ten centimeters or more (Fogel, 1994). Fogel (1997) argues that nearly all of the reduction in mortality from the late eighteenth century to the late nineteenth century, and half of the mortality improvement in the twentieth century, can be attributed to improved nutrition. It is important to note that he does not measure increased nutrition directly. Rather, he uses height as a measure of accumulated past nutritional experiences during years of growth, and then infers nutrition's positive effects on life expectancy from the positive relationship between height and life expectancy during the 18th and 19th centuries.

While Fogel's work has been widely acclaimed, the causal link between nutrition and population increase remains an unsettled question. Various cross-sectional studies from England between

\footnotetext{
${ }^{1}$ The sources of the population and urbanization data are discussed in Section 3.

${ }^{2}$ For studies in the growth literature that have focused on the link between population increase and factors such as per capita incomes see Galor and Weil (2000), Jones (2003), and Voigtländer and Voth (2006). For micro-level studies of the determinants of increased life expectancy see the literature review provided by Cutler, Deaton, and Lleras-Muney (2006).

${ }^{3}$ Within Europe, life expectancy at birth hovered around 25 years until at least the 15th century (Russell, 1948). After the 15th century there is some evidence of sporadic and at times temporary increases in life expectancy. According to data from Wrigley, Davies, Oeppen, and Schofield (1997), life expectancy in England had increased to 34 years by the 1540 s, then increased further to 38 years by the 1620s, before falling to 35 years by the 1730s. By the early 19th century, life expectancy had risen to 41 years and by 1900 it was 50 years. England's surge in life expectancy, starting in the 18th century, is also observed in other parts of the World. In France, life expectancy rose from 25 years in the 1740 s to 39 years by 1820 (Blayo, 1975). By the 19th century, life expectancy in Sweden and Japan was also well over 35 years (Maddison, 2001, p. 29).
} 


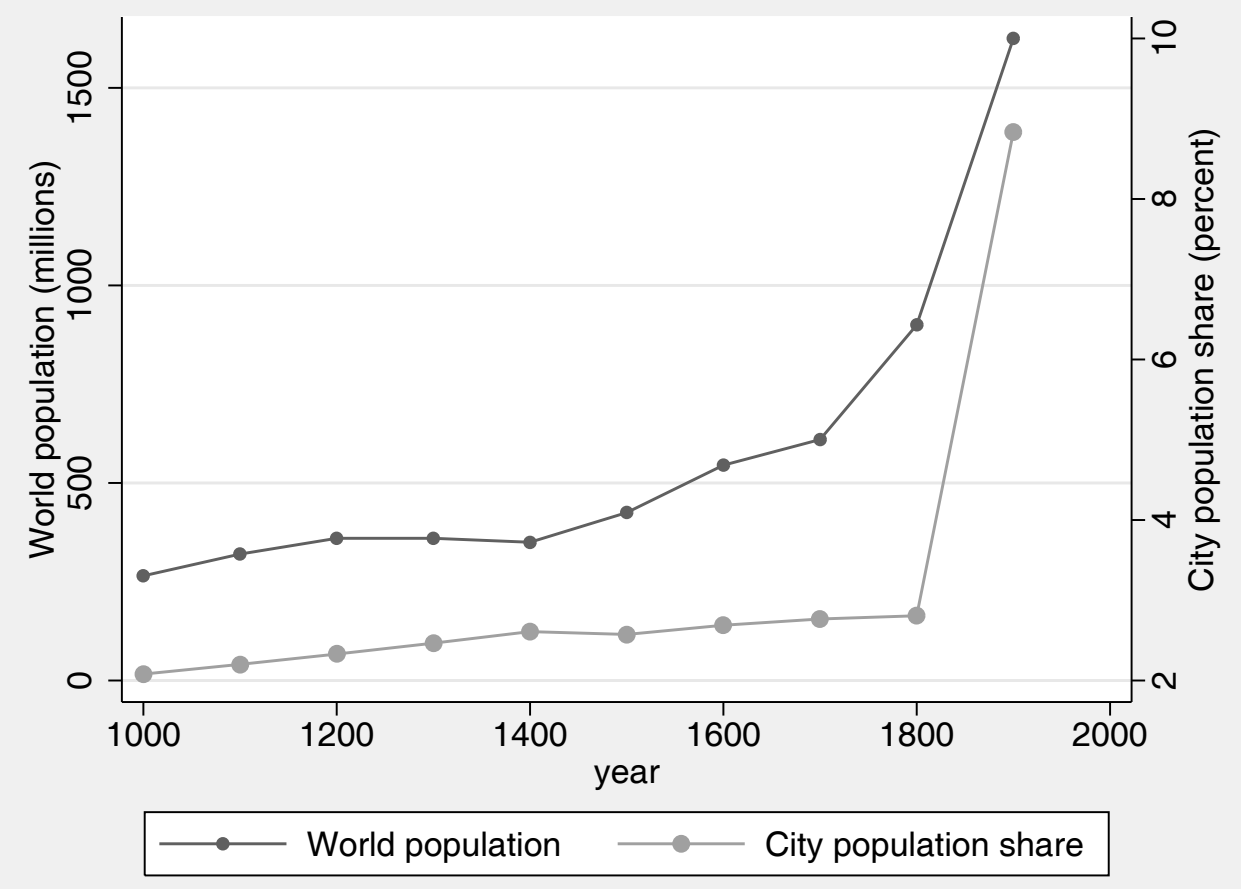

Sources: See text.

Figure 1: Growth in world population and urbanization, 1000-1900.

the 16th and 18th centuries, and from the British colonies in America during the same period, fail to provide evidence that wealthier or better nourished populations had lower mortality and longer life expectancy (Livi-Bacci, 1991). Moreover, the traditional view is that the most important contributors to increased life expectancy are the improvements in modern medicine and public sanitation that occurred during the end of the nineteenth century and the beginning of the 20th century. ${ }^{4}$ In reality, improvements in nutrition, medicine, and public sanitation, all likely contributed to the observed increase in life expectancy and population. This, along with the fact that improvements in each factor typically occurred simultaneously, makes identifying the effects of any one channel very difficult.

Our study contributes to the debate by providing causal estimates of the impact of improved nutrition on population growth. We estimate the effect of improved nutrition caused by the large increase in availability of calories and nutrients that followed the introduction of the potato from the New World to the Old World. ${ }^{5}$ We do not attempt a comparison of the importance of nutrition

\footnotetext{
${ }^{4}$ Preston $(1975,1980,1996)$ famously discusses the importance of public sanitation. For examples of the evidence of medical improvement on mortality, see Cutler (2004) and Cutler, Deaton, and Lleras-Muney (2005).

${ }^{5}$ Throughout the paper we use a broad definition of 'Old World', which includes the entire Eastern Hemisphere. In other words, by 'Old World' we do not mean Europe only.
} 
relative to medicine or sanitation. Instead, our goal is to causally identify the importance of nutrition by estimating the effect of one positive shock to nutrition on subsequent population growth. Because this shock occurred more than two centuries before improvements in modern sanitation and medicine, the results can be plausibly interpreted as reflecting the benefits of improved nutrition only.

We also estimate the effect of the introduction of potatoes on the share of population living in cities. The estimates provide evidence of the importance of agricultural productivity in spurring the transition from rural agriculture to urban manufacturing. A productivity shock in agriculture could have two potentially offsetting effects on urbanization. On the one hand, it may delay urbanization as workers become more attracted to the agricultural sector. On the other hand, the increased agricultural productivity means more workers can be freed from agriculture, allowing them to migrate to the cities and work in industry. Our estimates of the effect of the introduction of potatoes on urbanization provide historic evidence of the net effect of a significant positive agricultural productivity shock on the movement of labor from the countryside into cities. ${ }^{6}$

Any study attempting to estimate the causal effects of improved nutrition faces two main empirical difficulties, both of which arise because of the endogeneity of nutritional improvements. The first is the problem of reverse causality. For example, Cullen (1968) argues that in Ireland, population expansion led to the adoption of the potato, and not the other way around as many others have argued. ${ }^{7}$ In this case, the correlation between improved nutrition and population may reflect the reverse-causal effect of population on nutrition. The second problem arises from the existence of potentially omitted variables. Population growth and improved nutrition may both be outcomes of an unobserved factor, such as political stability.

The principal contribution of our study is to provide a strategy that helps resolve these problems. Our estimation exploits the introduction of the potato to the Old World following the discovery of the Americas. This event, together with geographic and climatic variation in a country's ability to cultivate and adopt the new food crop, provides a source of variation in nutrition that is plausibly exogenous to other factors that affect population growth. Because potatoes are superior to existing crops in terms of both calories and nutrition, we proxy for access to improved nutrition

\footnotetext{
${ }^{6}$ The existing empirical literature has found it very difficult to establish causality when looking at the relationship between agriculture and development. The best macro-level studies attempt to infer the effect of agriculture on economic development by examining panel data and employing lags and Granger causality tests (Tiffin and Irz, 2006).

${ }^{7}$ For others arguing reverse causality see Salaman (1949) and Connell (1962). Also, see the empirical evidence from Mokyr (1981).
} 
with the amount of land that is suitable for cultivating potatoes. Our empirical strategy is similar to a differences-in-differences (DD) estimation. We compare the levels and changes in Old World population and urbanization before and after the introduction of potatoes between regions that were suitable for cultivating potatoes and regions that were not suitable. Because our estimates are identified from the interaction between time (from the introduction of potatoes) and country characteristics (suitability for potato adoption), we are able to control for time-invariant country characteristics (country fixed effects), as well as country-invariant differences in the time periods being examined (time-period fixed effects).

Despite the existence of country fixed effects in our estimating equation, country characteristics may still bias our estimates if they affect population or urbanization differentially during the period after the adoption of potatoes as a field crop relative to before. We address this possibility by controlling for the interaction of potentially important country characteristics with an indicator variable for the post-adoption period. The set of controls in our baseline specifications include interactions with three alternative measures of agricultural suitability - the overall suitability of a country for growing any agricultural plant or crop, suitability for growing Old World staple crops (e.g., rice and wheat), and the suitability for growing New World staple crops (e.g., maize and sweet potatoes) - as well as interactions of geographic measures potentially correlated with potato suitability. Because potatoes were particularly suitable for cultivation on rugged terrain at high elevations, we also control for these two geographic characteristics in our estimates.

Our results show that Old World regions that were suitable for potato cultivation experienced disproportionately faster population and urbanization growth after the introduction of potatoes. The estimates are extremely robust to a variety of sensitivity checks, including the omission of outliers and influential observations, the omission of Western Europe, the inclusion of the countries north of Mezzo America, and the inclusion of a host of additional control variables.

The magnitudes of our estimates are also interesting. One way to measure the estimated effects is to ask how much of the average difference in population or urbanization levels (or their growth rates) between the pre-potato adoption period (1000-1700) and the post-adoption period (17001900 ) is explained by the introduction of the potato. Doing this calculation, our baseline estimates suggest that the potato accounts for $12 \%$ of the increase in population, $22 \%$ of the increase in population growth, $47 \%$ of the increase in urbanization, and $50 \%$ of the increase in urbanization growth. 
The notion that the introduction of the potato dramatically increased agricultural productivity, which resulted in increased population growth, has long been recognized by historians (e.g., Langer, 1963, McNeill, 1948, 1999, Salaman, 1949). William Langer (1963, p. 14) argues that in Europe "the spread of the potato culture everywhere corresponded with the rapid increase of population". Historians have, in fact, attributed even greater significance to the potato. McNeill (1999, p. 67), in an article title "How the Potato Changed World History", argues that "potatoes, by feeding rapidly growing populations, permitted a handful of European nations to assert domination over most of the world between 1750 and 1950".

Our study contributes to the historical literature by providing empirical estimates of the effect of the potato on population and urbanization. Only one previous paper has empirically examined the effect of the introduction of the potato. This is the study by Joel Mokyr (1981), which estimates the relationship between potato cultivation and population growth across Irish counties in 1845 . To address problems arising from the endogeneity of potato adoption, Mokyr estimates a system of two equations using 2SLS. He finds that potato cultivation resulted in a statistically significant increase in population growth. He also finds no evidence that the potato was adopted in response to rapid population growth. ${ }^{8}$

Our study differs from Mokyr's (1981) in two important ways. First, our difference-indifferences estimation strategy is very different from Mokyr's IV strategy. Our estimates are identified not by variation in the cross-section only, but from the interaction of regional variation in potato suitability together with time variation arising from the introduction of potatoes from the New World. Second, our study also examines the impact of potatoes beyond the Irish context and over a longer time horizon. Therefore, we are able to provide estimates of the full impact of potatoes on population and urbanization across the Old World during the 18th and 19th centuries.

The paper is organized as follows. Section 2 discusses the background on potatoes. Section 3 describes the data, Section 4 presents the empirical strategy, and Section 5 discusses the results. Section 6 offers concluding remarks.

\footnotetext{
${ }^{8}$ The only other piece of empirical evidence about the effects of the potato, although indirect, is from Baten and Murray (2000). The authors examined the determinants of the heights of 4,100 men and women that were incarcerated and sent to two prisons in Bavaria between 1856 and 1908. Included as a control variable in their analysis was the per capita production of potatoes in the prisoner's region of birth. According to their estimates, men and women from regions with greater potato production were taller. This was also true for regions with greater milk production, but was not the case for the production of bread grains, which was negatively correlated with heights.
} 


\section{Potatoes}

\section{A. Nutrition}

From a nutritional standpoint, there are two primary reasons why the potato is superior to other staple crops. First, because potatoes contain nearly all important vitamins and minerals, they support life better than any other crop when eaten as the sole article of diet (Davidson, Passmore, Brock, and Truswell, 1975, Reader, 2008). ${ }^{9}$ Humans can subsist healthily on a diet of potatoes, supplemented with only milk or butter, which contain the two vitamins not provided for by potatoes, vitamins A and D (Connell, 1962, Davidson et al., 1975). ${ }^{10}$ This, in fact, was the typical Irish diet, which although monotonous, was able to provide sufficient amounts of all vitamins and nutrients (Connell, 1962).

According to the U.S. Department of Agriculture (2007), a medium potato (150 g/5.3 oz) with the skin provides $29.55 \mathrm{mg}$ of vitamin C ( $45 \%$ of the daily value (DV)). This is important since the other staple crops, such as wheat, oats, barley, rice, and maize, do not contain any vitamin C, a necessary deterrent for scurvy. For much of the Old World, the potato provided the only source of vitamin $\mathrm{C}$ and protection against scurvy. ${ }^{11}$ A medium potato also contains $632 \mathrm{mg}$ of potassium (18\% of DV), $0.44 \mathrm{mg}$ of vitamin B6 (20\% of DV), as well as significant amounts of thiamin, riboflavin, folate, niacin, magnesium, phosphorus, iron, and zinc. Moreover, the fiber content of a potato with skin (3.5 grams) is similar to that of many other cereals such as wheat.

The second remarkable fact about the potato is that it yields more energy per acre of land than Old World cereal crops, and also requires less labor input (Langer, 1963, pp. 11-12; Connell, 1951, p. 391). Historic evidence of the caloric superiority of the potato over pre-existing Old World crops is shown in Table 1. The table reports data collected by Arthur Young (1771) in a survey of farming communities throughout England in the 1760s. The first two columns compare the average yields of oats, wheat, barley, and potatoes. As shown, yields (measured in either bushels or kilograms)

\footnotetext{
${ }^{9}$ Nutritionists Davidson and Passmore (1965, p. 285) write that "the potato is the only single cheap food that can support life when fed as the sole article of diet." (emphasis in the original text).

${ }^{10}$ Milk is not actually necessary for vitamin D since humans produce it after absorbing sunlight.

${ }^{11}$ As an example, the average Irish diet of 4.5 to 6.5 kilograms of potatoes per day provided 40 to 60 times the quantity of vitamin $C$ required to prevent scurvy (Hughes, 2000). An alternative source of vitamin $C$ in the Old World, before the arrival of potatoes, came from turnips (although potatoes provide more vitamin $\mathrm{C}$ than turnips). Turnips were also relatively hardy in cold weather. Some have argued that they played an important role in providing nutrition for places such as England (see Timmer (1969), and the references therein, for detailed studies of the role of turnips). However, relative to a potato, it provides fewer nutrients, and more importantly, it provides less than one-quarter the calories (U.S. Department of Agriculture, 2007).
} 
Table 1: Average crop yields of English farms in the 18th century.

\begin{tabular}{|c|c|c|c|c|}
\hline & \multicolumn{2}{|c|}{ Average Yield per Acre } & \multirow{2}{*}{$\begin{array}{c}\begin{array}{c}\text { Energy Value } \\
\text { of Crop }\end{array} \\
\text { Megajoules } \\
\end{array}$} & \multirow{2}{*}{$\begin{array}{c}\text { Acres of land needed } \\
\text { to provide } 42 \text { MJ per } \\
\text { day for one year }\end{array}$} \\
\hline & Bushels & Kilograms & & \\
\hline Wheat & 23 & 650 & 8,900 & 1.70 \\
\hline Barley & 32 & 820 & 11,400 & 1.40 \\
\hline Oats & 38 & 690 & 9,300 & 1.60 \\
\hline Potatoes & 427 & 10,900 & 31,900 & 0.50 \\
\hline
\end{tabular}

are well over ten times higher for potatoes relative to the other crops. This partly reflects the fact that potatoes are $75-80 \%$ water and are therefore naturally heavier and more bulky than the other crops. The third column compares the energy value of the yields reported in the first two columns. As shown, an acre of potatoes yield approximately three times more energy than the other crops. The final column reports this fact in a slightly more intuitive manner. It shows the number of acres required to provide the total energy needs for a family of two adults and three young children, which is estimated to be 42 mega joules (or approximately 10,000 calories) per day. While this family could subsist by cultivating a plot of only a $1 / 2$ acre of potatoes, it would need to cultivate about 1.5 acres - three times as much land - if it were to grow wheat, oats, or barley. The data from Table 1 confirm historic reports that a single acre of land cultivated with potatoes and one milk cow was nutritionally sufficient for feeding a large family of six to eight (McNeill, 1999, Langer, 1963).

Potatoes also had two additional benefits that further increased the amount of calories available. First, due to easy storage during the winter, potatoes provided excellent fodder for livestock. This meant that potatoes increased both meat available for consumption and manure which was used as an input in agriculture. Second, potatoes increased the productivity of land that was already used for cultivating grain crops. Typically, between $1 / 3$ and $1 / 2$ of the land under grain cultivation was left fallow each year. This was a strategy that was undertaken to control weeds. One benefit of potatoes was that they could be planted on the fallow land between periods of grain cultivation (Mokyr, 1981, McNeill, 1999). Thus, even when land was not converted from the cultivation of grains to the cultivation of potatoes, the introduction of the potato still increased the total supply 
of food from a given plot of land.

\section{B. Diffusion from the New World to the Old World}

Archeological evidence suggests that the potato was first cultivated in the Andes between 7,000 and 10,000 years ago (Messer, 2000b). After the discovery of the Americas by Christopher Columbus in 1492, the potato was soon introduced to Europe by the Spanish in the late sixteenth century. It was first cultivated in the Spanish Canary Islands around 1570. The first record of potatoes being cultivated as a staple crop was in England in the 1690s, where the potato was used as a supplement to bread (Langer, 1963, McNeill, 1999). ${ }^{12}$

By historical standards, the diffusion of the potato throughout Europe was rapid if not instantaneous. By most accounts, it took less than the time necessary for the 13th and 14th Century diffusion of gunpowder through Europe. ${ }^{13}$ The rapid adoption is all the more surprising since at first the potato was generally viewed either as a strange exotic gift and botanical curiosity, or as a poisonous and dirty plant that caused leprosy (Langer, 1975). Adoption was probably encouraged by failures of existing crops during the "Little Ice Age" and the wars and famines of the period. In many countries, adoption was also encouraged by policy. For example, in 1744, Prussia's Frederick the Great ordered his subjects to grow potatoes as insurance against cereal crop failure and distributed free seed potatoes with instruction on how to plant them. The French scientist Antoine Parmentier, influenced by his observation of the benefit of potatoes in Prussia during the Seven Years War (1756-1763), devoted his research to investigating and extolling the virtues of the potato. Once persuaded to plant potatoes, European farmers quickly recognized their advantages over other crops, and soon potatoes became the staple field crop they are today. By the late 18th century, potatoes, with the encouragement of government policy, had become an important field crop in countries such as France, Austria, and Russia. (Langer, 1963, McNeill, 1999).

The potato was spread to other parts of the Old World by European mariners who carried potato plants to ports across Asia and Africa. Although we do not have historical evidence on

\footnotetext{
${ }^{12}$ The first documented introduction of potatoes to continental Europe was in 1601 when Carolus Clusius reported in his Rariorum Plantarum Historia that he had seen potatoes planted in Northern Italy (McNeill, 1999, p. 73).

${ }^{13}$ There is some debate on whether gunpowder was first introduced to Europeans during the wars with the Islamic empires or during the Mongol invasion. In either case, it first was introduced to Europeans during the early to mid 13th century and became widely used by the end of the 14th and beginning of the 15th centuries in European warfare (Parker, 2000).
} 
the exact date of its first introduction, the existing evidence suggests that the potato was probably brought to the Philippines in the late 16th century and later brought to Java in the 17th century by the Dutch (Burkill, 1935). It's introduction to China probably occurred several times during the seventeenth century. It was cultivated as early as 1603 by Dutch settlers of the Penghu Islands, and later in Taiwan after the Dutch occupied the island from 1624 to 1662 . Given the Dutch initiation of trade links between Taiwan and the coastal province of Fujian, it is likely that the potato was also introduced to mainland China during this time. There is evidence from a document, dating back to 1700, of potato cultivation in a mountainous area of northern Fujian. According to Lee (1982, p. 738), by 1800 the populations in Southwest China had replaced the traditional lower yield crops of barley, oats, and buckwheat with either potatoes or maize, another New World crop. ${ }^{14}$ By the mid 19th century, potatoes had become an important field crop in Manchuria and the Korean Peninsula.

Historic evidence suggests that the potato first reached India not much later than Europe, taken there either by the British or the Portuguese. The earliest known reference to the potato in India is from an account by Edward Terry, who was chaplain to Sir Thomas Roe, British ambassador to the court of the Mughal Emperor Jahanagir from 1615 to 1619, in Northern India. British colonial governor Warren Hastings promoted potato cultivation during his term from 1772 to 1785 . By the late eighteenth century, potatoes were well established in the hills and plains of India (Pandey and Kaushik, 2003).

The introduction of potatoes to Africa is not well documented. The first written account suggests that it arrived slightly later than other parts of the world, around the end of the 19th century. In Ethiopia, the potato was introduced in 1858 by a German immigrant named Wilhelm Schimper. Subsequent adoption by native farmers occurred gradually over a period of several decades.

As the historic evidence illustrates, the actual date when the potato was adopted as a field crop varied across the Old World within a 150-year window. This was due in large part to idiosyncratic factors, such as the views of individuals and the ability and desire of governments to promote the adoption of the crop. For our estimates, we wish to avoid having our estimates affected by the timing of adoption, which was endogenous and potentially determined by a host of factors that may bias our estimates. Instead we use the initial date of the introduction of potatoes as a field crop to continental Europe, the earliest adopter of potatoes, as the date of when potatoes become

\footnotetext{
${ }^{14}$ In our analysis, we are careful to control for the effects of maize and other New World food crops.
} 
"available" as a staple food to the Old World. This date is in the late 1600s. Because our data are only observed at the century level, we take 1700 as the approximate treatment date.

Before taking this date as given, we first let the data "speak" by estimating a flexible equation that allows the effect of potatoes to vary for each century. This enables us to compare the timing of the effect observed in the data with the historical evidence before we impose greater structure on the data and estimate our main DD specification.

\section{Other New World Staple Crops}

After the discovery of the Americas, other New World crops, in addition to potatoes, were also introduced to the Old World. These include maize, tomatoes, chilli and bell peppers, cacao, and the sweet potato. Of these, the two crops that became high-caloric staples in the Old World are maize and the sweet potato.

Maize is unable to rival potatoes in terms of nutrients or calories. It produces significantly fewer calories per acre of land. Further, humans are unable to subsist on a diet that is too concentrated in maize. Significant consumption of maize is associated with Pellagra, which is a disease caused from niacin deficiency. The effects of Pellagra include skin disorders, digestion disorders, mental disorders, and eventually death. The disease was first observed in the 1730s in Italy and even today continues to affect poor populations with diets that rely too heavily on corn. A second adverse effect of a primarily corn diet is protein deficiency (Messer, 2000a). Given the negative effects associated with diets too heavily dependent on corn, one would not expect corn to have the same positive effects as potatoes.

Sweet potatoes are also nutritious and produce similar amounts of calories per acre of land as potatoes. But they differ from potatoes in two important ways. First, the archaeological evidence suggests that sweet potatoes, transported by Polynesians, reached the Old World long before the European discovery of the New World. For many countries in our sample, their impact would have been felt as early as $1000 \mathrm{AD}$ (Hather and Kirch, 1991). Second, a close substitute to the sweet potato, the yam, already existed in the Old World (O'Brien, 2000). Yams are broadly similar to sweet potatoes both in terms of nutritional content and the requirements for cultivation. Many regions that were suitable for cultivating sweet potatoes had already cultivated yams when the former were introduced. Therefore, the sweet potatoes would not be expected to result in the same increase in agricultural productivity and caloric-availability as potatoes. 
In our empirical analysis, we are careful to make sure that our results are robust to controlling for any potential effects of other New World staple crops.

\section{Data}

\section{A. Crop Suitability}

Our analysis uses a measure of a region's suitability for growing potatoes, as well as measures of the suitability of Old and other New World staple crops. To construct these variables, we rely on data from the FAO's Global Agro-Ecological Zones (GAEZ) 2000 database. The data measure the suitability for cultivating individuals crops at a very disaggregated geographic level.

The construction of the FAO's GAEZ database occurred in two stages. The FAO first collected information on the characteristics of 154 different crops. These data were used to determine what environmental conditions are required for the cultivation of each crop. The FAO then compiled data on the physical environment of 2.2 million grid-cells, spanning the entire globe. Each grid-cell is 0.5 degrees by 0.5 degrees, which is approximately 56 kilometers by 56 kilometers (measured at the equator). The primary characteristics used are climatic and are taken from a global climatic database that has been compiled by the Climate Research Unit (CRU) at the University of East Anglia. In total, nine variables from the global climatic database are used by the FAO: precipitation, frequency of wet days, mean temperature, diurnal (i.e. daily) temperature range, vapor pressure, cloud cover, sunshine, ground-frost frequency, and wind speed. The second set of characteristics are land characteristics and are taken from the FAO's Digit Soil Map of the World (DSMW), except for the information on the slope of soils, which are from the GTOPO30 Database developed at the U.S. Geological Survey (USGS) EROS Data Center.

Combining the information on the constraints for the cultivation of each crop with the data on the physical environment of each grid-cell, the FAO calculated an estimate of the potential yield of each crop in each grid cell, given an assumed level of crop management and input use. This process involved a number of detailed steps, which we briefly summarize here.

First, for each grid-cell and crop, the FAO identified the days of the year when the moisture and thermal (i.e., temperature) requirements of the crop are met. With this information, the FAO determined the exact starting and ending dates of the length of growing period (LGP) for each 
crop and grid-cell (the growing period is, by definition, the period of time for which the minimum temperature and moisture requirements of the crop are satisfied).

At this stage, an initial classification of each grid-cell and crop pair was performed. If the minimum requirements for cultivation were not satisfied, then the grid-cell was determined to be unsuitable for cultivation of the crop. ${ }^{15}$ If the minimum requirements are met, then a second stage is performed where the actual potential yields are determined. For each crop, the "constraint-free crop yields" were determined, and the yield in each grid-cell was measured as a percentage of this benchmark. Next, the FAO identified additional constraints existing in each grid-cell for each crop. The procedure quantified the "agro-climatic" constraints (i.e., variability in water supply and existence of pests and weeds) as well as the "agro-edaphic" suitability (i.e., soil erosion) of each grid-cell.

The end product of the entire procedure is, for each crop, a GIS raster file with global coverage that contains information on the suitability of each grid-cell for the cultivation of the crop in question. The FAO also constructed a country level version of the database, which reports for each country and crop, the proportion of the country's land that is classified under five mutually exclusive categories describing how suitable the environment is for growing the crop. The categories are based on the calculated percentage of the maximum yield that can be attained in each grid-cell. The five categories, and their corresponding yields, are: $(i)$ very suitable land (80-100\%), (ii) suitable land (60-80\%), (iii) moderately suitable land (40-60\%), (iv) marginally suitable land $(20-40 \%)$, and $(v)$ not suitable land $(0-20 \%)$. To approximate historical conditions as closely as possible, we use the variables constructed under the assumption that cultivation occurs under rain-fed conditions and under medium input intensity.

\footnotetext{
${ }^{15}$ This is done by comparing each crop's requirements with the grid-cell's calculated (i) length of the growing period (LGP), (ii) temperature profile, (iii) and the accumulated temperature.
} 


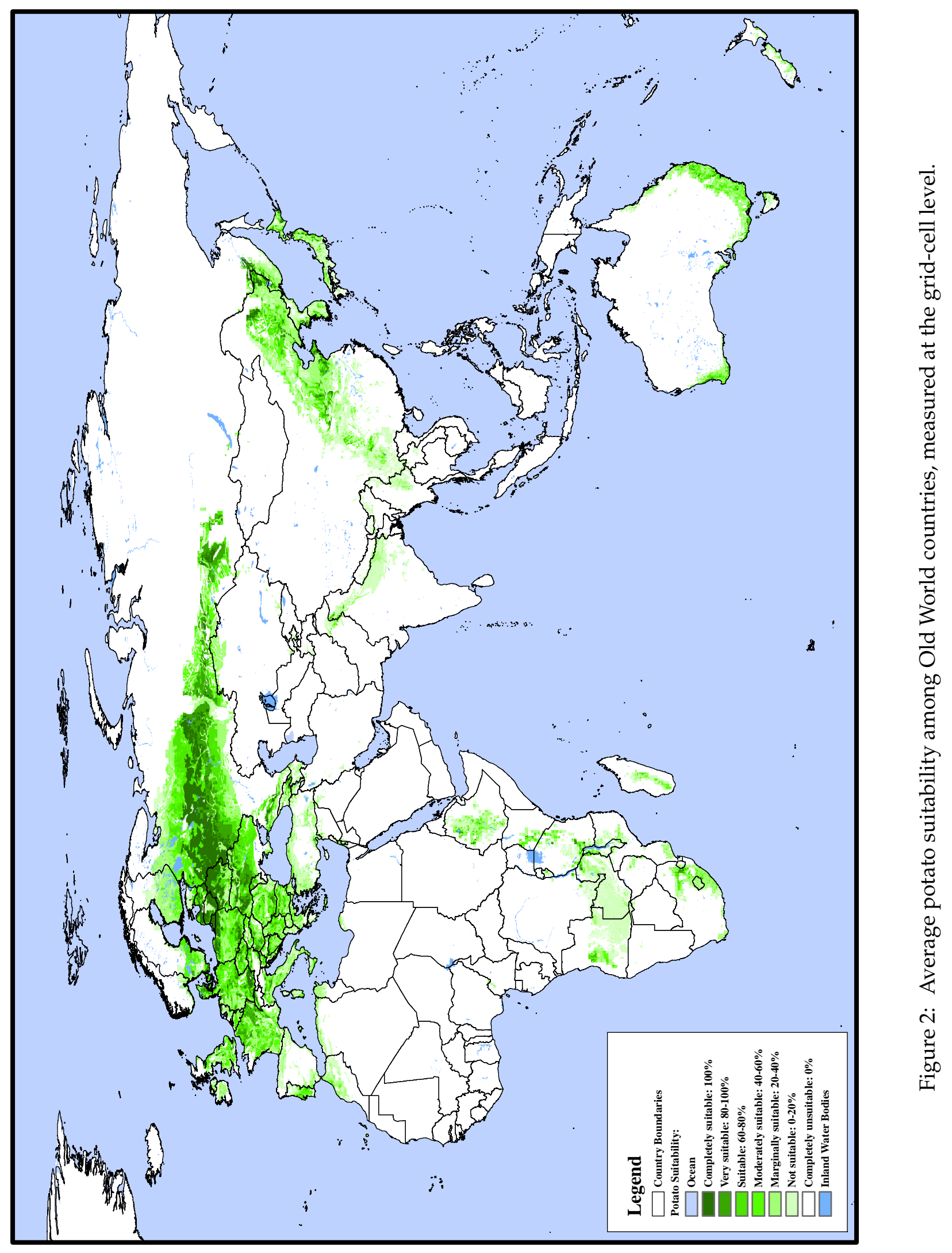


We define land to be suitable for cultivation if it is classified in the database as being either "very suitable", "suitable", or "moderately suitable". Put differently, our measure defines land to be suitable if it yields at least $40 \%$ of the maximum possible yield. ${ }^{16}$ Our baseline measure of a country's suitability for growing potatoes is the fraction of each country's land area that is defined as suitable based on our definition. Note that because the FAO does not report the distribution of suitability within each category, we are unable to calculate a measure of average suitability for each country. We can only calculate the fraction of land that falls into different categories.

Figure 2 illustrates the FAO's suitability measures at the grid-cell level for the Old World countries of our sample. The map shows grid-cells classified according to the five categories above. Also shown are the extreme grid cells for which $100 \%$ of the maximum potato yield is obtainable and for which $0 \%$ is obtainable. A darker shade corresponds to greater suitability.

A number of facts are immediately apparent from the map. The first is that much of the world is completely unsuitable for growing potatoes. The result of this is that 53 of the 130 Old World countries in our sample have a measure of land suitable for cultivating potatoes equal to zero. In our empirical analysis we pay particular attention to this fact, and show that our results are not being driven by zero suitability countries. We obtain similar results if we omit zero suitability countries from the sample.

The second fact that is apparent from Figure 2 is that much of the land area suitable for potato cultivation is concentrated in Europe. This fact is a potential cause of concern since we know that Western Europe diverged from the rest of the world after 1700. The underlying causes of this divergence may bias our estimated impact of the introduction of potatoes on population and urbanization. We address this concern explicitly in a number of ways. We show that our estimates do not change if we control for underlying determinants of Western Europe's divergent growth after the 18th century. Furthermore, we also show that our results are robust to the exclusion of Western European countries from our sample.

A final concern with our potato suitability measure is whether the measure calculated in the 1990s by the FAO is an accurate indicator of suitability two hundred years ago. The construction of the suitability measures gives us confidence that it is. The measures are based primarily on geographic characteristics that do not change over the period of our study, namely, temperature,

\footnotetext{
${ }^{16}$ The results are very similar when we use $20 \%$ or $60 \%$ of the maximum yield as alternative cut-offs. They are not reported for sake of brevity.
} 
humidity, length of days, sunlight, and rainfall. In constructing our measure, we also deliberately use the FAO measures that assume rain fed conditions, avoiding measurement error caused by changes over time in irrigation technology and intensities of irrigation use.

It is also important to recognize that factors that can respond quickly to human intervention, such as soil $\mathrm{pH}$ or slope, only enter the calculation in an indirect manner, and only have small effects on the underlying measures. Climatic characteristics, which are unaffected in any significant way by human actions, are the sole determinants of whether potatoes can be cultivated on a grid-cell. Conditional on their ability to be cultivated, the estimated productivity of a grid-cell is affected by factors that can be influenced by human actions, such as land characteristics like the $\mathrm{pH}$ and/or slope of the soil. As a robustness check, we also constructed an alternative measure of potato suitability that classifies any land that can cultivate potatoes, no matter how productively or unproductively, as being fully suitable for potato cultivation. This measure, although potentially less precise, has the benefit of being determined solely by climatic factors, and not by factors potentially influenced by human action. ${ }^{17}$ We find that our results are robust to the use of this alternative measure of potato suitability. For brevity the results are not reported in the paper, but are available upon request.

A second reason why our FAO-based variable may be an imperfect measure of suitability in the past is because of the evolution of new potato varieties overtime. Certainly, since the Potato Blight (Phytophthora infestans) of 1845 and 1846, there has been a concerted effort to develop new varieties. However, the effort was focused on developing new varieties with increased resistance to Phytophthora infestans, not on developing varieties that could be grown in new climates (Salaman, 1949 , pp. 159-166). In the 20th century, the focus was on developing varieties that were visually appealing to consumers. To this end, varieties were developed that were oval or kidney-shaped, had a uniform skin color, and were without sprouts in their pits. The other major objective has been the development of varieties that are resistant to 'dry rot', which can develop during transit (Salaman, 1949, pp. 169-171). In short, the development of new potato varieties has not focused on creating varieties that can be grown in new locations. Therefore, it is very unlikely that the development of new varieties results in measurement error that biases our estimates in any

\footnotetext{
${ }^{17}$ Recall that climatic factors only are used by the FAO to initially determine if a location is suitable or not. If an area is suitable, then additional factors, including soil characteristics, are used to determine just how suitable the area is. The alternative measure that we construct captures the first stage of the procedure only, and therefore is unaffected by the factors most likely influenced by human actions.
} 
significant way.

As a check of the sensibility of our potato suitability measure, we examine whether our measure is correlated with historic potato production. The earliest period for which data are available for a cross-section of countries is 1900. These data are from Mitchell $(1998,2003)$. We construct the natural logarithm of tons of potato production per capita and examine its relationship with our potato suitability measure. The correlation between the two variables, measured by the standardized beta coefficient, is 0.42 . This is statistically significant at the $1 \%$ level. The correlation is similar if we also include New World countries in the sample, or if we control for a measure of overall agriculture suitability (which we describe in detail below). The positive correlation between potato suitability and historic potato production provides added confidence in the validity of our measure.

In our analysis, we also control for the suitability of Old World staple crops and for New World staple crops. These measures are also constructed using data from the FAO's GAEZ database. We define Old World staple crops to be wetland rice, dryland rice, and wheat; and New World crops to be grain maize, silage maize, sweet potatoes, and, of course, the potato. For both aggregate measures, we take the maximum of the shares of land that are suitable for growing each of the component crops. ${ }^{18}$ In other words, the measures are the fraction of land that can grow the most suitable Old World and New World staples, respectively. ${ }^{19}$

The FAO database also provides a composite measure of the suitability of an area for growing any agricultural crop for human consumption (i.e., not including crops for fodder). The measure, which captures the suitability of 154 crops, is much broader than our constructed measures of the suitability for cultivating Old World staple crops or New World staples. The measure of overall agricultural suitability also includes: other cereals, such as sorghum, millet, rye, and barley; other roots, such as cassava; pulses, like beans, chickpeas, and cowpeas; oil crops, such as the soybean, groundnuts, sunflower, palm oil; fiber crops, such as cotton; sugar crops, like sugarcane and sugar beets; and fruit crops, such as bananas and plantains. We include this measure as an additional control to capture a country's overall agricultural productivity. ${ }^{20}$

In our analysis we also consider city-level measures of suitability. We construct the city-level

\footnotetext{
${ }^{18}$ As with our potato suitability measure, here (and for all other measures) we define land to be suitable for cultivation if it is classified as either "very suitable", "suitable", or "moderately suitable".

${ }^{19}$ An alternative strategy is to measure the union of the land that was suitable for all the crops in each category. In other words, this measure is the fraction of land that can grow any Old World and New World crop. These alternative controls yields very similar estimates. Unsurprisingly, the two measures are highly correlated.

${ }^{20}$ The raw correlations between a country's potato suitability and its suitability for growing Old World staple crops, New World staple crops, and all crops are reported in Appendix Table A1.
} 
measures manually using the FAO's finer grid-cell level GIS raster data. For each city, we define the relevant agricultural region to be a circle with a $100 \mathrm{~km}$ radius originating from the city. Suitability for the city is then the fraction of land within the circular region that is suitable. ${ }^{21}$

\section{B. Outcome Variables}

The historic populations of individuals living on land that today is a modern country are from McEvedy and Jones (1978). In our analysis, we examine the level of population in the following years: 1000, 1400, 1500, 1600, 1700, 1800, and 1900. We do not use the years 1100, 1200, and 1300. This is because the population fluctuations due to the Black Death cause these data to be particularly unreliable.

We also examine the average annual population growth rate between each time period. This is calculated in the standard manner:

$$
\text { Population growth }{ }_{i t}=\frac{\ln \left(\text { Population }_{i t}\right)-\ln \left(\text { Population }_{i t-n}\right)}{n}
$$

where $n$ is 100 years, except when $t=1400$; then $n=400$.

We examine the effects of potatoes on the growth of population not because we believe the introduction of the potato had permanent growth effects. Instead, our interest is in testing whether the introduction of potatoes increased the carrying capacity of land, thereby increasing the population that could be supported on it. Because the transition to the higher population may occur over centuries, the introduction of potatoes may have affected the growth rate of population in the centuries following its introduction. Therefore, we view our population growth estimates as alternative robustness estimates to our population level estimates.

We also examine the effect of potatoes on urbanization. Data on the populations of urban centers are from Chandler (1987), Bairoch (1988), and Modelski (2003). We measure a country's total urban population to be the number of people living in cities with more than 20,000 inhabitants. We construct each country's urbanization rate by dividing its total urban population by its total population taken from McEvedy and Jones (1978). We measure the urbanization rate in percentage terms; it therefore ranges from zero to 100.

\footnotetext{
${ }^{21}$ We have also tried other distances from a city in our analysis. The results are robust to the use of either 200 or 500 kilometer radii.
} 
We also examine the average annual change in the urbanization rate between time periods. This is calculated as follows:

Change in city population share ${ }_{i t}=\frac{\text { City population share }_{i t}-\text { City population share }_{i t-n}}{n}$

where as before $n$ is 100 , except when $t=1400$; then $n=400$.

Urbanization is an interesting outcome to examine, in and of itself, because it reveals whether the net effect of the positive shock to agriculture caused by the introduction of potatoes facilitated the movement of people to cities. However, urbanization can also be taken as a proxy for historic industrialization and income per capita. ${ }^{22}$ A number of studies have shown that, historically (and today), urbanization rates serve as a good proxy for per capita GDP (DeLong and Shleifer, 1993, Acemoglu, Johnson, and Robinson, 2002, 2005). In particular, Acemoglu et al. (2002) document the strength of the correlation between urbanization and per capita income. ${ }^{23}$

Accuracy is an obvious concern for historic data that spans such a long time horizon and broad cross section. McEvedy and Jones (1978), which is the standard source for historic population data at the country level, provide detailed discussions of the sources used to construct their population estimates. It is important to keep in mind that measurement error in our outcome variables will not bias our regression estimates as long as it is random. Systematic variation in the error either by time period or by country are addressed by country and year fixed effects. As a robustness check, we also estimate the effect of potatoes on city population growth. Since the historic populations for larger urban centers are generally thought to be more confidently known than for smaller rural towns, this provides an alternative estimate of population growth based on data that are potentially more accurate (Bairoch, 1988, pp. 524-525). ${ }^{24}$ Similar findings using the data at the country and city levels will give us confidence in the country-level data.

Our country-level sample consists of 132 Old World countries. With the exception of seven countries, each country is observed in each time period. Our city-level sample consists of 1,143 Old World cities (i.e., locations with over 20,000 people). The number of cities observed increases each

\footnotetext{
${ }^{22}$ Because per capita income data are unavailable prior to 1500, and even in 1500 they are only available for 22 Old World countries, we are unable to examine the effect of the introduction of potatoes on income directly.

${ }^{23}$ Using the most extensive historic income data available, which are from Maddison (2003), we have also examined the relationship between urbanization and income back to 1500. In a panel setting with either country fixed effects and/or year fixed effects, we find that the correlation between urbanization and income is extremely strong and highly significant.

${ }^{24}$ The clear draw back of the city-level analysis relative to the country-level is that, although a country's suitability for potatoes is clearly defined, the suitability of a 'city' is far from clear. For this reason, we use the country as our standard unit of analysis, and rely use the city-level estimates only as a robustness check.
} 
century. Of the 1,143 cities, only 308 are observed in 1800, 214 in 1400, and by 1000 we only observe 77 cities. As we discuss below, our estimated coefficients do not differ dramatically depending on whether we use the full sample of 1,143 or restrict the sample to obtain a more balanced panel. Summary statistics are reported in Appendix Table A2.

\section{Estimating Equations}

Our first estimating equation imposes very little structure on the data and simply examines how the relationship between a country's suitability for growing potatoes and each of our four outcomes of interest varies over time. Our estimating equation is:

$$
Y_{i t}=\sum_{j=1400}^{1900} \beta_{j} \text { Potato }_{i} \times I_{t}^{j}+\sum_{j=1400}^{1900} \delta_{j} \text { All Crops }_{i} \times I_{t}^{j}+\sum_{c} \gamma_{c} I_{i}^{c}+\sum_{j=1400}^{1900} \rho_{t} I_{t}^{j}+\varepsilon_{i t}
$$

where $i$ indexes countries and $t$ indexes time periods, which are for the years 1000, 1400, 1500, $1600,1700,1800$, and 1900. $Y_{i t}$ denotes our outcome of interest, either population, average annual population growth, the urbanization rate, or the average annual change in the urbanization rate. The equation includes country fixed effects $\sum_{c} I_{i}^{c}$, which capture average time invariant differences in country characteristics that affect the outcome variable. Similarly, the time period fixed effects $\sum_{j} I_{t}^{j}$ capture time specific shocks that affect all countries. We control for the share of land suitable for overall agriculture interacted with the time period dummy variables $\sum_{j} \delta_{j}$ All Crops $s_{i} \times I_{t}^{j}$ to ensure that the effect of introducing potatoes is not confounded by other changes in the importance of agricultural productivity over time. All Crops ${ }_{i}$ is the fraction of land that is suitable for growing any crop for human consumption.

The variable Potato $_{i}$ measures the fraction of land in country $i$ that is suitable for the cultivation of potatoes. By interacting the variable with each of the time period indicator variables, we are able to estimate a period specific relationship between potato suitability and the outcome variable. These are the $\beta_{j}$ 's is equation (1), which are our coefficients of interest. If population or urbanization increased due to the adoption of potatoes after 1700, then we expect to find that after this date, countries with greater potato suitability experienced disproportionately faster growth.

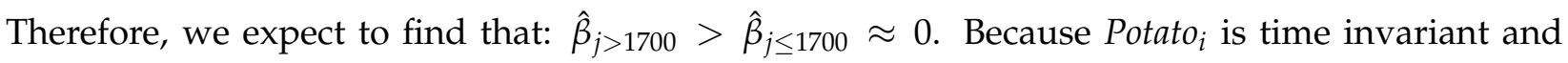
the equation includes country and time-period fixed effects, the estimated $\beta_{j}$ 's must be measured relative to a baseline time period, which we take to be $1000 \mathrm{AD}$. 
Our second estimating equation examines the impact of the introduction of potatoes in a more structured manner, using a strategy that is similar to differences-in-differences estimation. This strategy compares the outcome of interest before and after the introduction of potatoes across countries with varying suitability for potato cultivation. Given the endogeneity of the date of adoption, we use the approximate date of the introduction to Europe, 1700, rather than the actual date of adoption. We also continue to use a country's suitability for cultivating potatoes rather than the extent of actual cultivation.

We estimate the following baseline equation.

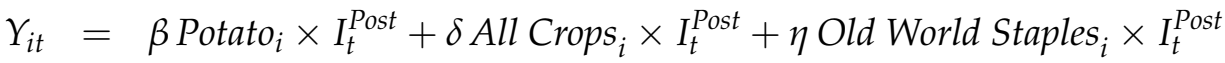

$$
\begin{aligned}
& +\phi \text { New World Staples }{ }_{i} \times I_{t}^{\text {Post }}+\mathbf{X}_{i}^{\prime} \mathbf{I}_{t}^{\text {Post }} \mu+\sum_{c} \gamma_{c} I_{i}^{c}+\sum_{j=1400}^{1900} \rho_{t} I_{t}^{j}+\varepsilon_{i t}
\end{aligned}
$$

As before, $Y_{i t}$ denotes one of our four outcomes of interest, and $\sum_{c} I_{i}^{c}$ and $\sum_{j} I_{t}^{j}$ denote country and time period fixed effects. Our measure of potato suitability, Potato ${ }_{i}$, is now interacted with an indicator variable that equals one after 1700, $I_{t}^{\text {Post }}$. All Crops ${ }_{i}$, Old World Staples ${ }_{i}$, New World Staples ${ }_{i}$ indicate our suitability measures for overall agriculture, Old World staples, and New World staples. We control for these measures, each interacted with a post-1700 indicator variable.

Our coefficient of interest is $\beta$, which is the estimated impact of potato suitability on the difference in the outcome variable before and after 1700. For concreteness, consider population growth as the dependent variable. The estimated coefficient, $\hat{\beta}$, measures the additional population growth rate experienced by countries that are suitable for potatoes relative to those that are not, after potatoes were introduced in 1700 (relative to before). If the coefficient is positive, then this indicates that countries with a geographic environment more suitable for growing potatoes witnessed a greater increase in population growth after 1700 relative to before 1700.

In our analysis, we are also careful to control for various geographic characteristics, which may be correlated with potato suitability and may have affected population differentially after 1700 relative to the period prior to this date. Because one of the benefits of potatoes is that they can be grown on rugged terrain at high levels of elevation, in our estimates we are particularly careful to control for a country's average elevation and ruggedness. ${ }^{25}$ The vector of interaction controls is denoted by $\mathbf{X}_{i}^{\prime} \mathbf{I}_{t}^{\text {Post }}$ in equation (2).

\footnotetext{
${ }^{25}$ Details of these measures are reported in Tables A1 and A2 of the Appendix. Table A1 reports the pair-wise correlations between suitability for potatoes and the two geographic controls, and Table A2 reports summary statistics.
} 
Our estimation strategy has all of the potential advantages and hazards of standard DD estimators. Country fixed effects control for all time invariant factors that differ between countries. Time period fixed effects control for any secular patterns of population growth or urbanization that affect all regions similarly. Our identification relies on the assumption that conditional on the controls, there are no other events, also occurring around 1700, that may have affected population or urbanization. This assumption should not be taken for granted since there were many changes during the 18th and 19th centuries which could have affected population or urbanization. In the section on robustness, we will consider and control for a large number of alternative country characteristics and historic events that may potentially confound our estimates. We discuss this in more detail in the Section 5C.

One important caveat when interpreting our results is that the strategy literally estimates the effect of suitability conditional on the introduction of potatoes, rather than the effect of the introduction of potatoes. As with any "experiment", our estimates cannot directly estimate the effect of potatoes relative to a counterfactual state of the world where potatoes do not exist. To use our results to shed light on the overall effect of the introduction of potatoes, there must not be spillovers between countries. In Section 5B we test for the presence of spillover effects, and show that they are estimated to be very close to zero.

\section{Estimation Results}

\section{A. Flexible Estimation}

We begin with estimates for our flexible estimating equation (1). The estimates are reported in Appendix Table A3 and visually in Figures 3 and 4. The figures show for each of our four outcome variables - population, population growth, urbanization, and change in the urbanization rate the relationship in each time period, between the outcome of interest and, either the suitability for potato cultivation, or the suitability for overall agriculture. These coefficients are the $\beta_{j}$ 's and $\delta_{j}$ 's in equation (1). The $y$-axes of the figures are identical in scale so that the magnitudes of the coefficients can be easily compared. Because equation (1) includes time-period and country fixed

effects, the estimated coefficients for Potato $_{i} \times I_{t}^{j}$ and AllCrops $s_{i} \times I_{t}^{j}$ must be measured relative to a baseline time period, which we take to be the year 1000. Therefore, the figures show the estimated relationship between suitability in the dependent variable relative to the relationship in 1000 AD. 


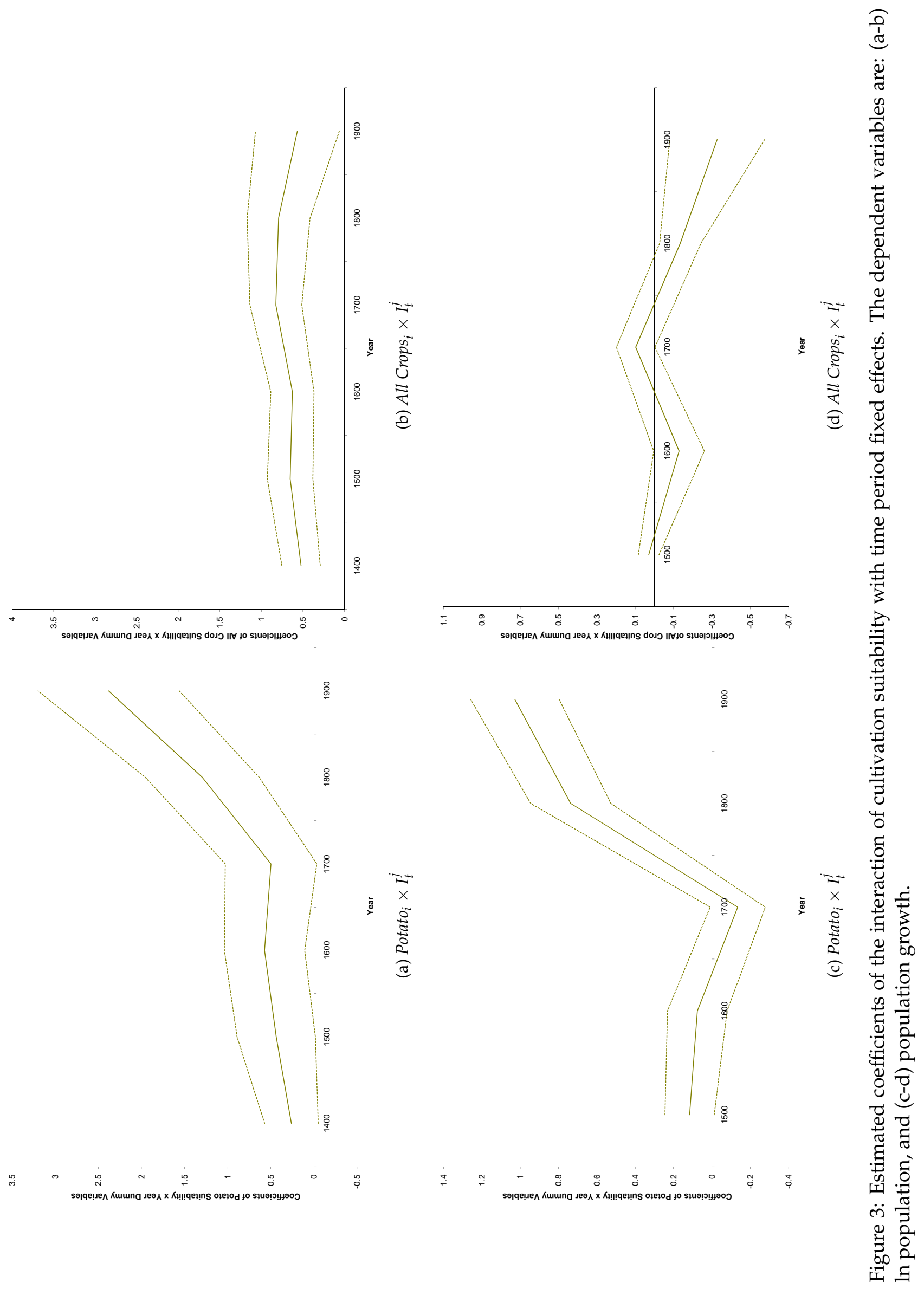




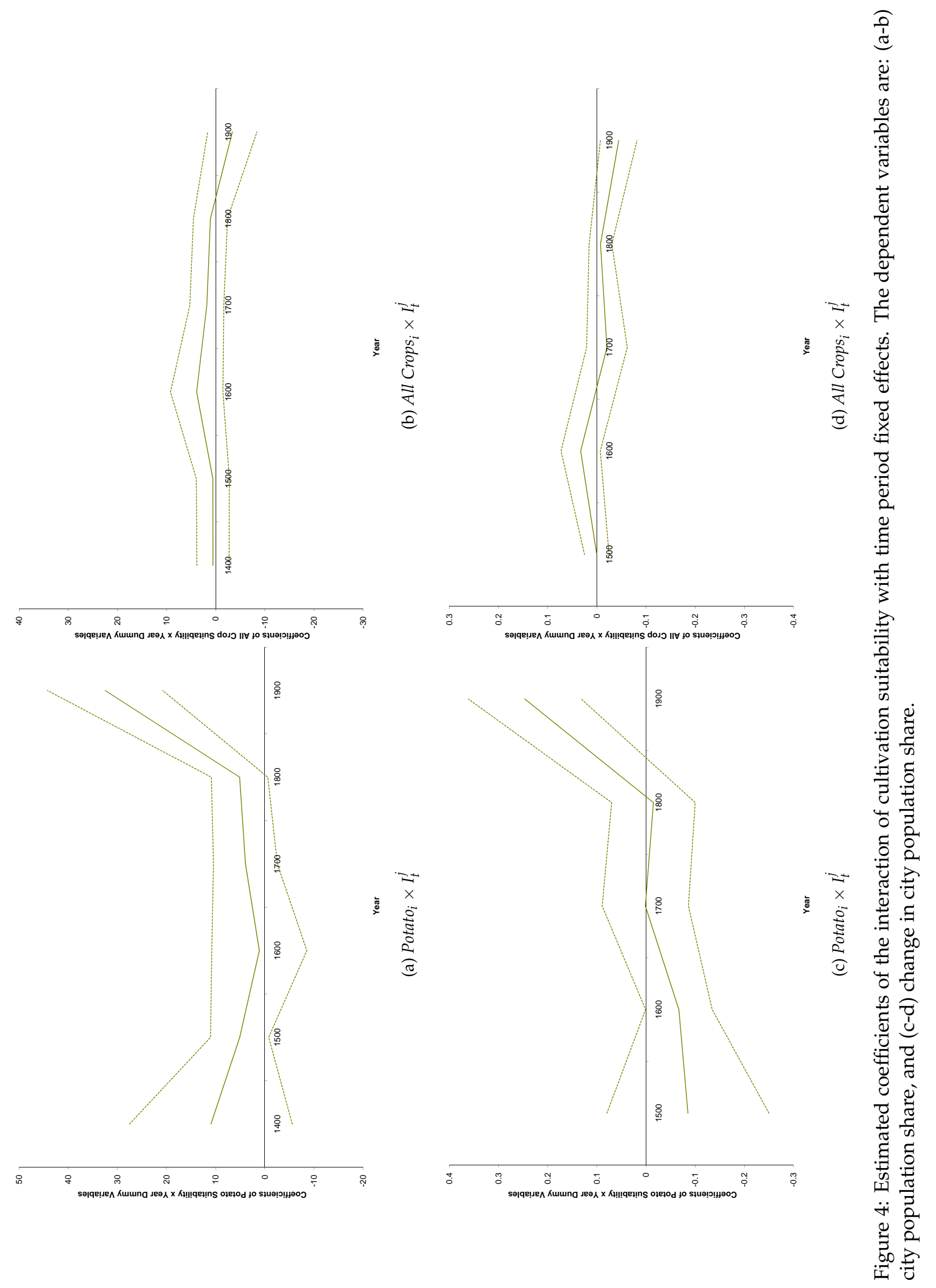


Figures 3 and 4 show that potato suitability had little effect between 1400 and 1700. But, beginning in 1700, countries more suitable for potato cultivation began to experience faster population growth and faster increases in urbanization. In contrast, the figures show that the correlation between agricultural suitability and the outcomes of interest did not change systematically over time. These patterns are similar for all four outcomes.

The figures also show that the effect on urbanization is delayed by roughly one century relative to the effect on population. This should be interpreted only as a rough approximation of the length of the delay because our data are at the century level. Hence, any effects on urbanization that occurred after the middle of the 18th century, for example, will show up in our results as a one century delay. In any case, the difference in timing between the effect on population and urbanization is consistent with potatoes having an immediate effect on population growth, but a delayed effect on the movement into cities.

\section{B. Preliminary Differences-in-Differences Population Estimates}

Given the historic and empirical evidence for 1700 being the key date of potato adoption, we now turn to our main estimating equation (2), which explicitly assumes that potatoes were adopted after this date. We begin by reporting preliminary estimates focusing on population as the outcome variable (i.e., ln population and population growth). The estimates are reported in columns (1) and (2) of Table 2. Recall that in addition to controlling for All Crops ${ }_{i}$, equation (2) also controls for our measure of suitability for growing Old World staple crops, New World staple crops, and for average terrain ruggedness and elevation, each interacted with the post-1700 indicator variable.

Table 2 also reports a number of preliminary sensibility checks. We first address the quality of our historic country-level population data. We do this by reporting alternative estimates based on city-level population data. Although it is difficult at best to measure the ability of a city to adopt potatoes, the use of city-level data has the advantage that historic city populations are arguably more accurately known than historic country-level populations. ${ }^{26}$ Therefore, the alternative citylevel estimates provide a check of the sensibility of our country-level results.

\footnotetext{
${ }^{26}$ There is little information on the actual distances that potatoes traveled when moving from the countryside into cities, except statements that it generally was not very far. Salaman (1949) reports that potatoes consumed in cities were obtained from local gardens and nearby rural villages. In our analysis, have used different distances from each city when constructing our city-level suitability measures. The results are robust if, rather than using 100 kilometers, we use either a 200 or 500 kilometer radius.
} 
Table 2: Country- and city-level difference-in-differences estimates.

\begin{tabular}{|c|c|c|c|c|c|c|c|c|}
\hline & \multicolumn{2}{|c|}{ Country level } & \multicolumn{2}{|c|}{ City level } & \multicolumn{4}{|c|}{ Country level } \\
\hline & (1) & (2) & (3) & (4) & (5) & (6) & (7) & (8) \\
\hline & In Population & $\begin{array}{l}\text { Population } \\
\text { growth }\end{array}$ & In Population & $\begin{array}{l}\text { Population } \\
\text { growth }\end{array}$ & In Population & $\begin{array}{l}\text { Population } \\
\text { growth }\end{array}$ & In Population & $\begin{array}{c}\text { Population } \\
\text { growth }\end{array}$ \\
\hline Potato $\times$ Post & $\begin{array}{c}1.236 \\
(0.291)\end{array}$ & $\begin{array}{c}0.741 \\
(0.118)\end{array}$ & $\begin{array}{c}0.942 \\
(0.308)\end{array}$ & $\begin{array}{c}0.638 \\
(0.251)\end{array}$ & $\begin{array}{l}1.335 \\
(0.314)\end{array}$ & $\begin{array}{c}0.816 \\
(0.169)\end{array}$ & $\begin{array}{c}2.135 \\
(1.023)\end{array}$ & $\begin{array}{c}1.024 \\
(0.460)\end{array}$ \\
\hline Neighbors' Potato x Post & & & & & $\begin{array}{c}0.065 \\
(0.456)\end{array}$ & $\begin{array}{l}-0.026 \\
(0.204)\end{array}$ & & \\
\hline Potato $\times$ Old World Staples $\times$ Post & & & & & & & $\begin{array}{l}-1.525 \\
(1.457)\end{array}$ & $\begin{array}{l}-0.481 \\
(0.670)\end{array}$ \\
\hline Observations & 922 & 790 & 885 & 649 & 922 & 790 & 922 & 790 \\
\hline
\end{tabular}

Columns (3) and (4) report the estimated effects of potatoes on population and population growth at the city level. To be as conservative as possible, we restrict our sample to locations that existed as cities (i.e., a population of more than 20,000) in at least one pre-adoption time period and at least one post-adoption period. The results are similar if we include all cities in the sample, even if they do not appear in a pre-adoption time period. ${ }^{27}$

Comparing the city-level estimates of columns (3) and (4) with the country-level estimates of columns (1) and (2), one finds that they are very similar. In both cities and countries, the introduction of potatoes has a positive and significant effect on population and population growth. The magnitude of the estimates are slightly larger at the country level, which could potentially be explained by the fact that the city-level estimates do not include the impact of potatoes on the rise of new cities. The fact that we obtain similar results when we use city-level and country-level population data is reassuring.

To interpret the DD estimates from columns (1) and (2) as literally the effect of potatoes on historic population, we must assume that countries that were unsuitable for cultivating potatoes were not affected in any way by the introduction of potatoes. This assumption is violated if there were either positive or negative spillover effects, so that countries that did not adopt potatoes were also affected when their neighbors adopted potatoes. Positive spillovers may have occurred through trade in agricultural products. If a neighboring trading partner adopted potatoes and

\footnotetext{
${ }^{27}$ A significant proportion of the cities in our full sample $(640$ of 1,143) appear only in 1900 . A total of 186 cities appear in at least one pre-adoption and one post-adoption time period.
} 
was able to effectively produce more calories, then this may have also benefitted its trading partners. ${ }^{28}$ Negative population spillovers could have occurred through migration. An increase in a neighboring country's suitability may have negatively affected a country's population if there was movement out of the country and to the neighboring country that adopted the potato. Because our estimates are identified from comparisons between potato-suitable and non-suitable regions, any positive spillovers will attenuate our estimated impact of potatoes, while negative spillovers, will cause our estimates to overstate the true effect of potatoes.

In columns (5) and (6), we test for the existence of spillovers. This is done by constructing, for each country, a measure of the average suitability of all adjacent countries i.e., Neighbors' Potato $_{i} \times$ $I_{t}^{\text {Post }}$. We then include this measure in our baseline estimating equation (2). The estimation results fail to provide any evidence for the presence of spillover effects. The estimated coefficients for Neighbors' Potato $_{i} \times I_{t}^{\text {Post }}$ are very small in magnitude and statistically insignificant. Given the lack of evidence for spillovers, we can be more confident that our DD coefficients provide consistent estimates of the effect of potatoes on historic population. ${ }^{29}$

The final check that we perform is motivated by the notion that potatoes may have had the greatest benefit in regions that were less suitable for pre-existing staple crops. We test for this by allowing the impact of potatoes to differ depending on whether a country was suitable for the production of Old World staple crops. This is done by including Potato ${ }_{i} \times I_{t}^{\text {Post }} \times$ Old World crops $_{i}$ in our baseline estimating equation. Columns (7) and (8) show that the estimated interaction terms are negative, providing some evidence that potatoes had smaller benefits in regions that were more suitable for existing staple crops. However, the coefficients should be interpreted cautiously since they are not statistically significant.

\footnotetext{
${ }^{28}$ The fact that potatoes are not highly traded does not rule out the possibility of positive spillovers from trade. A region may adopt potatoes and only consume the potatoes domestically. Because potatoes are much more efficient to produce, this may free up resources for the production of other, more freely tradable crops.

${ }^{29}$ We have also undertaken alternative tests to ensure that migration, in particular, is not affecting our estimates. We have estimated equations where the dependent variable is the "natural change" in the population of each country, which we calculate as the change in the total population that was not the result of either in- or out-migration. This was done by taking the McEvedy and Jones (1978) population data and subtracting the net immigration for the century. The migration data are from Mitchell $(1998,2003)$. The estimated impact of potatoes on population, using this alternative measure of non-migration induced population increases, are nearly identical to the baseline estimates reported here. An alternative strategy is to estimate our baseline equations controlling for net migration in the 100 years prior to period $t$. Our estimates remain virtually unchanged when we do this.
} 


\section{Baseline Differences-in-Differences Estimates}

Having addressed the two largest issues facing our estimates - the quality of the historic country level population data, and the existence of spillover effects - we now turn to our baseline DD estimates, and report country-level estimates for all four of our outcomes of interest: population, population growth, city population share, and change in the city population share. The estimates are reported in columns (1) and (7) of Table 3. As shown, we find a positive and statistically significant effect of the introduction of the potato on both urbanization and the change in the urbanization rate. Consistent with our flexible estimates, the DD estimates also show that potatoes had a positive effect on the rise of cities.

The remaining columns of the table show the robustness of our baseline estimates to alternative specifications. In columns (2) and (8), we interact each of our baseline control variables with a full set of time period fixed effects. As the estimates show, our results are fully robust to allowing our set of covariates to have a completely flexible effect on population and urbanization over time.

In columns (3)-(6) and (9)-(12) of Table 3, we report estimates, including additional control variables that may capture alternative determinants of differential growth in certain parts of the world after 1700. The fact that a large fraction of Europe is suitable for potatoes raises the concern that our estimates capture other factors that may have affected the divergence of Europe during this time period. One explanation for this divergence is that many European countries benefited from a history of Roman rule (Jones, 1981, Landes, 1998). Acemoglu et al. (2005) construct a measure meant to capture this determinant of Europe's divergent growth: an indicator variable that equals one if a country was part of the Roman Empire. ${ }^{30}$ We control for the interaction of this variable with an indicator variable for the post-1700 period. Columns (3) and (9) show that our baseline estimates are robust to the inclusion of this control.

Another potentially confounding factor is the occurrence of the Black Death. If the plague, which killed up to $30 \%$ of Europe's population, was more severe in regions that were suitable for potatoes, then our estimates may overstate the true effect of potatoes. The coefficients in columns (4) and (10) show that our estimates are robust to controlling for the average annual growth rate of population between 1000 and $1400 .^{31}$

\footnotetext{
${ }^{30}$ This variable is taken from Acemoglu et al. (2005), who construct their measure using information from Langer (1972).

${ }^{31}$ In this specification, our sample is reduced by 12 observations since the pre-trend control variable cannot be constructed for two countries, New Zealand and Finland, because of missing population data for the year 1000.
} 


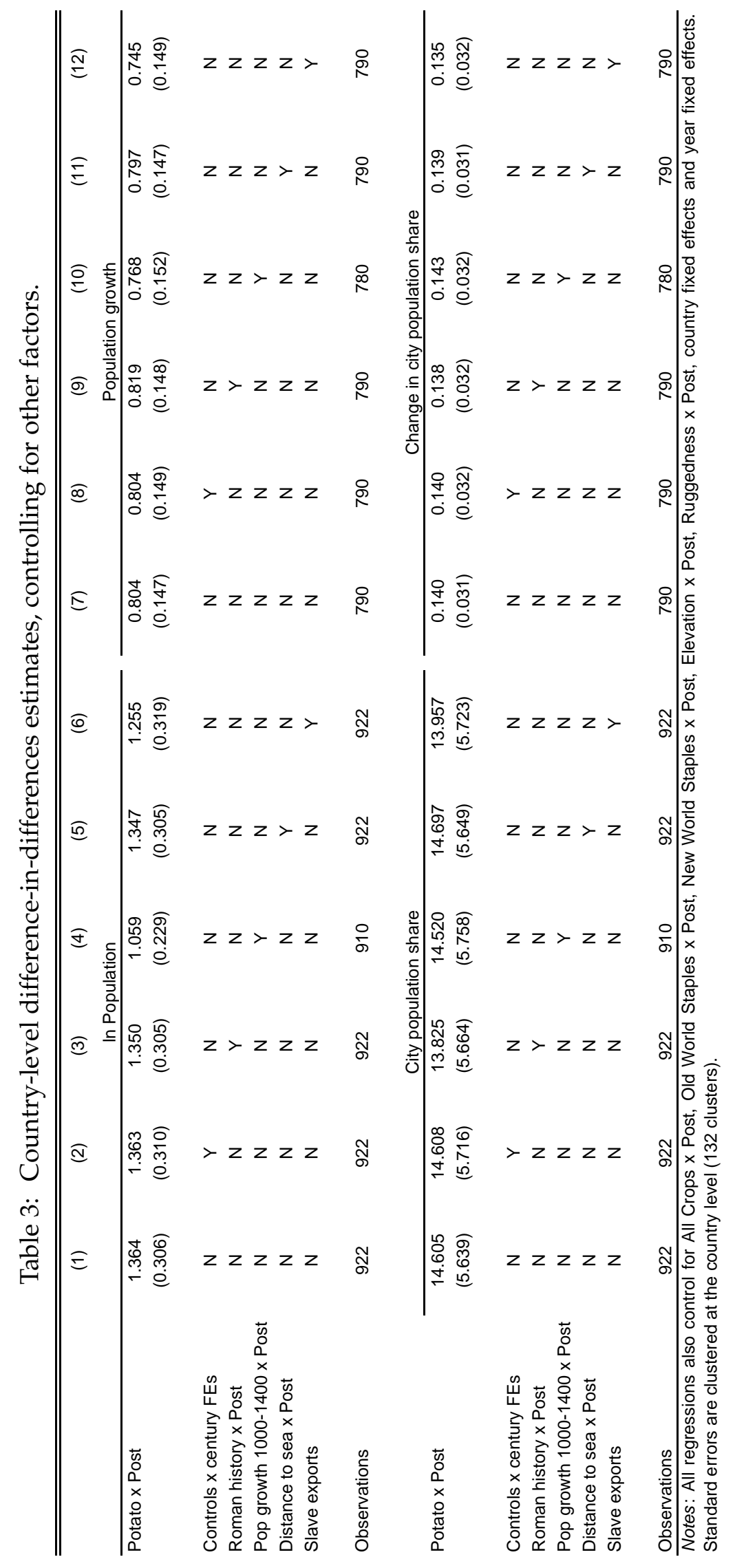


Next, we consider the fact that the spread of potatoes occurred during a period of increased globalization and overseas trade. Columns (5) and (11) show that our estimates are robust to controlling for an interaction between access to trade, which we proxy with a country's average distance from an ice-free coast, interacted with the post-1700 indicator variable. ${ }^{32}$

Finally, we consider the large global trade in slaves from Africa. The slave trades reached their height in the 18th century, which is approximately the same time that potatoes were being adopted globally. If the countries that were least able to adopt potatoes are also African countries that were depopulated because of the slave trade, then this may explain part of the effect of potatoes on increased population growth and urbanization after 1700. To capture the potential effects of Africa's slave trades, we include a country and time-period specific measure of the number of slaves taken during the 100 years prior to period $t$. The results are reported in columns (6) and (12). As shown, including this control has little effect on our estimated potato coefficients.

We next turn to the possibility that our baseline estimates are being driven by a few influential observations. Figure 5 shows the partial correlation plots between potato suitability and the outcomes of interest from the baseline estimates reported in columns (1) and (7) of Table 3. The eastern portion of the plots show that it is primarily the Eastern European countries such as Belarus (BLR), Latvia (LVA), Lithuania (LTU), and Poland (POL) that have the greatest leverage, or influence, on our estimates. The fact that the main beneficiaries from the introduction of potatoes are primarily Eastern European countries helps alleviate the concern that our estimates also capture benefits to population and urbanization from the industrial revolution or the rise in Atlantic trade. Eastern Europe did not participate in the Atlantic trade during this period. Nor did they experience the industrial revolution until the final decades of the 19th century (Stearns, 2007, pp. 90-94). Figure 5 also shows that Australia (AUS), New Zealand (NZL), Philippines (PHL), and Thailand (THA) are outliers, with either large positive or negative residuals. This is likely because these countries experienced large population changes, due to colonization, that were unrelated to potato cultivation.

To check that our results are not drive by these outliers, we re-estimate our baseline specification using a number of restricted samples that omit potential outlying observations. These are reported

\footnotetext{
${ }^{32}$ The measure of a country's average distance from an ice-free coast is taken from Nunn and Puga (2007). The results are also robust if we focus specifically on the lucrative Atlantic, which has been emphasized by Acemoglu et al. (2005). Our results are robust to controlling for an indicator variable that equals one if the country was an 'Atlantic trader', as defined by Acemoglu et al. (2005), interacted with a post-1700 indicator variable.
} 


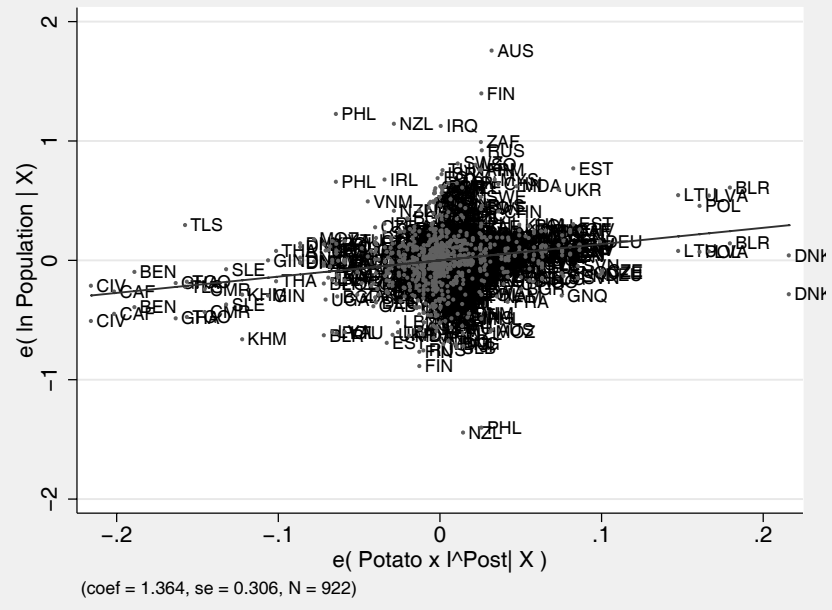

(a) Dep var: In population

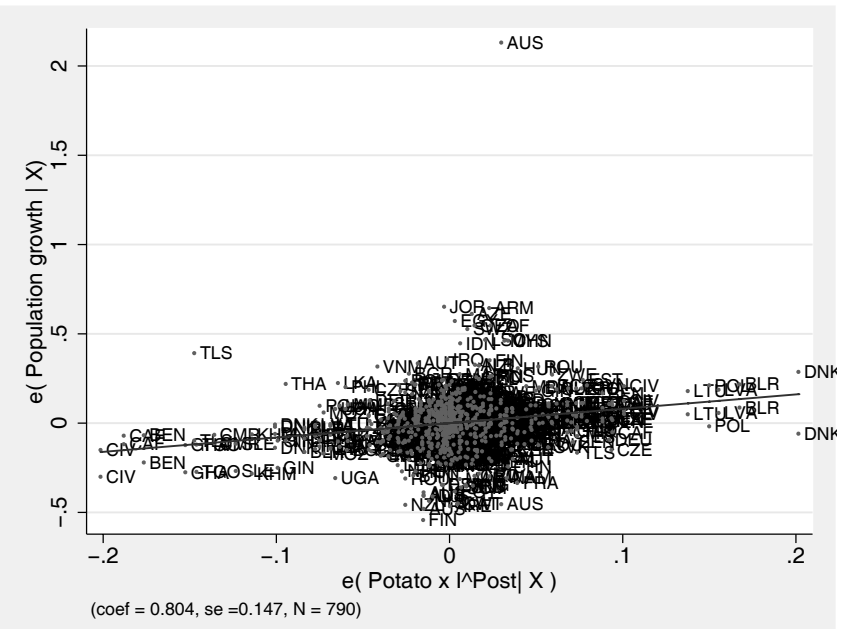

(b) Dep var: population growth

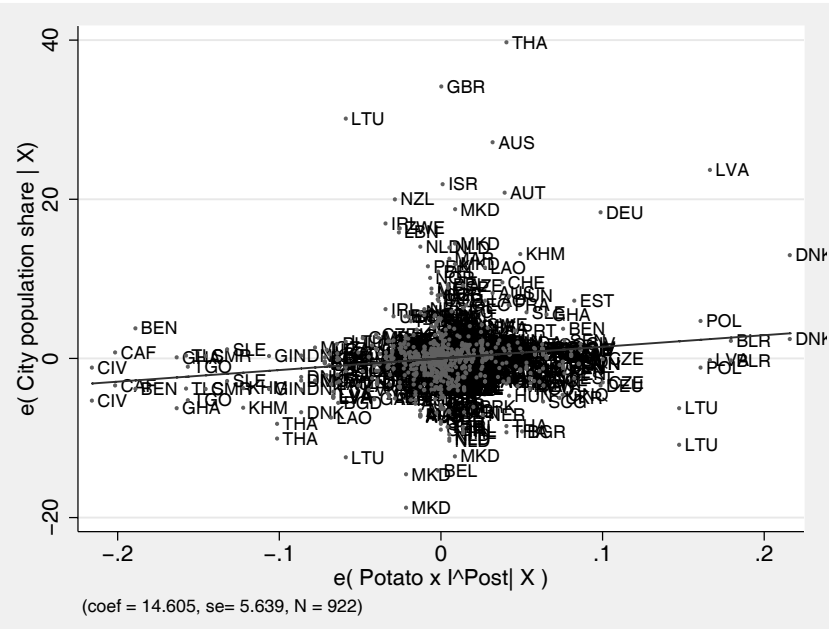

(c) Dep var: city population share

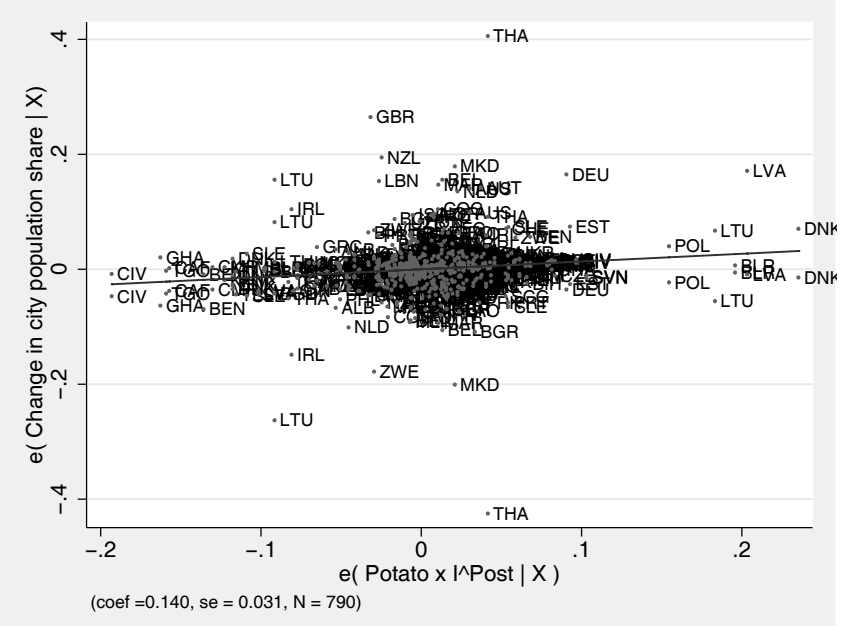

(d) Dep var: change in city population share

Figure 5: Partial correlation plot for the interaction of potato suitability with the post-1700 indicator variable. The dependent variable is (a) ln population, (b) population growth, (c) city population share, and (d) change in the city population share. 
Table 4: Robustness of the results to the removal of outliers and to different subsamples.

\begin{tabular}{|c|c|c|c|c|c|c|}
\hline & \multicolumn{6}{|c|}{ Subsamples } \\
\hline & $\begin{array}{c}\text { Baseline sample } \\
\text { (1) }\end{array}$ & $\begin{array}{c}\text { Omitting BLR, } \\
\text { DNK, LVA, } \\
\text { LTU, POL } \\
(2)\end{array}$ & $\begin{array}{c}\text { Omitting AUS, } \\
\text { NZL, THA, PHL } \\
\text { (3) }\end{array}$ & $\begin{array}{c}\text { Omitting zero } \\
\text { suitability } \\
(4) \\
\end{array}$ & $\begin{array}{l}\text { Excluding } \\
\text { Western } \\
\text { Europe } \\
(5) \\
\end{array}$ & $\begin{array}{c}\text { Including } \\
\text { Canada and } \\
\text { USA } \\
(6) \\
\end{array}$ \\
\hline & \multicolumn{6}{|c|}{ A. Dependent variable: In Population } \\
\hline \multirow[t]{2}{*}{ Potato x Post } & 1.364 & 1.437 & 1.520 & 1.880 & 1.581 & 1.418 \\
\hline & $(0.306)$ & $(0.426)$ & $(0.284)$ & $(0.583)$ & $(0.262)$ & $(0.314)$ \\
\hline \multirow[t]{2}{*}{ Observations } & 922 & 887 & 895 & 551 & 825 & 936 \\
\hline & \multicolumn{6}{|c|}{ B. Dependent variable: Population growth } \\
\hline \multirow[t]{2}{*}{ Potato x Post } & 0.804 & 0.845 & 0.799 & 1.077 & 0.881 & 0.847 \\
\hline & $(0.147)$ & $(0.213)$ & $(0.136)$ & $(0.279)$ & $(0.155)$ & $(0.154)$ \\
\hline \multirow[t]{2}{*}{ Observations } & 790 & 760 & 767 & 472 & 707 & 802 \\
\hline & \multicolumn{6}{|c|}{ C. Dependent variable: City population share } \\
\hline \multirow[t]{2}{*}{ Potato x Post } & 14.605 & 12.812 & 12.744 & 14.499 & 11.837 & 14.848 \\
\hline & $(5.639)$ & $(6.373)$ & $(5.385)$ & $(7.021)$ & $(6.274)$ & $(5.596)$ \\
\hline \multirow[t]{2}{*}{ Observations } & 922 & 887 & 895 & 551 & 825 & 936 \\
\hline & \multicolumn{6}{|c|}{ D. Dependent variable: Change in city population share } \\
\hline \multirow[t]{2}{*}{ Potato x Post } & 0.140 & 0.133 & 0.131 & 0.120 & 0.128 & 0.143 \\
\hline & $(0.031)$ & $(0.047)$ & $(0.030)$ & $(0.045)$ & $(0.037)$ & $(0.031)$ \\
\hline Observations & 790 & 760 & 767 & 472 & 707 & 802 \\
\hline
\end{tabular}


in Table 4. Column (1) reports our baseline estimates with the full sample of observations for comparison. Column (2) omits the influential Eastern European countries, and column (3) omits the observations with the largest residuals. These auxiliary estimates show that our baseline results are not sensitive to these potentially influential observations.

We now address a number of potential concerns related to our potato suitability measure. One concern is the large number of zero-suitability countries in our sample. Column (4) reports estimates with all zero-suitability countries omitted from the sample. Although, this reduces the sample size significantly, our results remain robust.

An additional concern with our suitability measure is that many suitable countries are Western European countries, which experienced the industrial revolution at approximately the same time potatoes were adopted. In Table 3 we attempted to control for potential determinants of the rise of Western Europe. Here, we pursue an alternative strategy and simply omit all Western European countries from our sample. ${ }^{33}$ Omitting these countries does not affect our estimates.

Because our identification strategy only applies to regions in which potatoes were not indigenous, our baseline sample contains only Old World countries. It is disputed whether potatoes were cultivated by the indigenous populations north of Mezzo America before their "re-introduction" by European settlers. Historians have found no evidence that they did, although there are no widely accepted theories of why the crop did not diffuse into these regions. Therefore, out of interest, we expand our sample to include the countries north of Mezzo America, namely Canada and the United States. ${ }^{34}$ The estimates are shown in column (6). They are very similar to the baseline estimates both in magnitude and statistical significance. These estimates should be interpreted cautiously, since potatoes may have already existed in America and Canada. Further, the native populations of the Americas suffered large negative population shocks due to diseases introduced by Europeans

\section{Magnitudes of the Estimates}

It is well known that after 1700 the world experienced an unprecedented increase in the growth of population and urbanization. This well established fact can be seen in Figure 1, which shows the evolution of World population and urbanization between 1000 and 1900. The figure shows that

\footnotetext{
${ }^{33}$ The Western European countries include: Belgium, Denmark, Germany, France, Finland, Great Britain, Ireland, Italy, Liechtenstein, Luxembourg, Netherlands, Norway, Portugal, Spain, Sweden, and Switzerland.

${ }^{34}$ Because FAO data are unavailable for Greenland, it is not included in the larger sample.
} 
relative to the pre- 1700 period, after 1700 there is an increase in both the level and the growth rate of population and urbanization. These facts are summarized for the Old World in the first three rows of Table 5. The first row reports averages for the pre-1700 period (1000-1700), the second row reports averages for the post-1700 period (1700-1900), and the third row reports the difference between the two periods. The table confirms that after 1700, Old World countries witnessed a significant increase in average population, population growth, urbanization, and the rate of change of urbanization.

As a way to illustrate the magnitude of our estimated effects of potatoes, we calculate how much of the observed differences between the pre- and post-adoption periods can be attributed to the introduction of the potato. On average, approximately $7.78 \%$ of a country's land is suitable for potato cultivation according to the definition used in this study. This is the fraction of land that could potentially be used to grow potatoes after 1700 . Prior to 1700 , since potatoes were not yet introduced, no Old World country was able to grow potatoes and therefore this number was $0 \%$. The introduction of potatoes, therefore, increased the average amount of land that could potentially be used for potato cultivation from 0 to $7.78 \%$.

Our DD estimates provide a measure of the impact of being able to cultivate potatoes on population and urbanization after 1700. We use our baseline estimates of the effect of potatoes on each outcome, reported in columns (1) and (7) of Table 3. These are reproduced in the fourth row of Table 5. Because the coefficients report the estimated impact on the relevant outcome from a one unit (i.e., 100\%) increase in a country's share of land suitable for potatoes, the average gain to an Old World country from the introduction of potatoes is given by the coefficient multiplied by the average increase in suitability, which is $7.78 \%$ or 0.0778 . These effects are reported in the sixth row of Table 5 .

The final row of the table reports how much of the difference between the pre- and post- 1700 periods can be attributed to the introduction of the potato. This is calculated as the difference between the two periods that is explained by potatoes (reported in row 6) divided by the observed difference between the two periods (reported in row 3). Doing this calculation for each of our four outcome measures, we find that the availability of potatoes can explain: $12 \%$ of the increase in population, $22 \%$ of the increase in population growth rate, $47 \%$ of the increase in urbanization, and $50 \%$ of the increase in urbanization growth.

While these effects are large, they are not as large as they may seem at first glance. Take for 
Table 5: Calculating the global effects of the introduction of potatoes.

\begin{tabular}{|c|c|c|c|c|c|}
\hline & & \multicolumn{4}{|c|}{ Outcomes } \\
\hline & & In Population & Population growth & $\begin{array}{c}\text { City population } \\
\text { share }\end{array}$ & $\begin{array}{c}\text { Change in city } \\
\text { population share }\end{array}$ \\
\hline (1) & Pre-adoption average: $1000-1700$ & -0.52 & 0.14 & 2.10 & 0.00021 \\
\hline (2) & Post-adoptoin average: $1800-1900$ & 0.36 & 0.42 & 4.53 & 0.02193 \\
\hline (3) & Difference between two periods: (2) -(1) & 0.88 & 0.29 & 2.43 & 0.02171 \\
\hline (4) & Estimated effect of being $100 \%$ suitable for potatoes & 1.364 & 0.804 & 14.605 & 0.140 \\
\hline (5) & Average suitability for potatoes & 0.078 & 0.078 & 0.078 & 0.078 \\
\hline (6) & Average effect of potato suitability: (4) $\times(5)$ & 0.106 & 0.063 & 1.138 & 0.011 \\
\hline (7) & Percent of change explained by potatoes: $(6) /(3) \times 100$ & $12.07 \%$ & $21.93 \%$ & $46.82 \%$ & $50.25 \%$ \\
\hline
\end{tabular}

example our figure of $22 \%$ for population growth. This does not mean that $22 \%$ of the total increase in population growth between 1000 and 1900 is explained by potatoes. Nor does it mean that $22 \%$ of the increase in population growth after 1700 is explained by potatoes. The statement is that after 1700 (i.e., 1700-1900), relative to the period before 1700 (i.e., 1000-1700), there was an increase in the average rate of population growth; it is $22 \%$ of this difference that is explained by the introduction of the potato.

\section{E. Heterogeneous Effects}

Until this point, we have been focused on the average effect of potatoes among Old World countries. The final exercise of the paper is to consider heterogeneity, and examine whether the effects of the potato differ systematically depending on certain characteristics.

We first consider the possibility that global trade may have been an important factor that was complementary to potato adoption. We test this possibility by using a country's average distance from an ice-free coast as a measure of its natural openness to overseas trade. We then include an interaction between this measure and Potato $_{i} \times I_{t}^{\text {Post }}$ in our baseline estimating equation. ${ }^{35}$ Estimates are reported Panel A of Table 6. The estimated effects are mixed. In the population regressions the triple interactions are positive and in the urbanization regressions they are negative. This indicates that potatoes had a smaller effect on population growth in naturally open countries, but a larger effect on urbanization in more open countries.

\footnotetext{
${ }^{35}$ We also control for the interaction of distance from the coast with the post-1700 indicator variable.
} 
Although seemingly counter-intuitive, there is a straight-forward explanation for the opposite differential effects from trade openness. First, consider population. The finding that the effects of local agricultural productivity shocks are reduced when an area is more integrated is a well established prediction of trade models. As a country becomes more integrated it becomes less responsive to domestic shocks and more responsive to foreign shocks. Donaldson (2008) provides a trade model applied to colonial India that highlights this effect of integration. He also provides evidence that increased integration made domestic prices less responsive to local weather shocks. Next, consider urbanization. If cities located in countries that were more engaged in overseas trade were more dynamic and had greater economic opportunities for workers, then the surplus labor generated from potato cultivation would have moved more extensively, and more quickly, into cities located in countries more open to trade. It is important to note, however, that the estimates should be interpreted cautiously, and as suggestive evidence only, since three of the coefficients are insignificant.

We also explore the possibility that labor was pulled into cities by growing labor demand (e.g., from industrialization) by examining whether a high initial demand for urban labor increased the benefits of potatoes. It is possible that regions with more developed cities and greater opportunities, exerted a greater pull on labor in the country side, resulting in faster urbanization growth after the adoption of potatoes. We test for this by taking the urbanization rate in 1700 as an admittedly imperfect proxy for pre-existing urban labor demand. We then test whether the benefits from potatoes were greater for countries with a higher urbanization rate in 1700 . The estimates are reported in Panel B of Table $6 .^{36}$ Across the four outcomes of interest, we do not observe any consistent pattern. Three of the four coefficients are negative, and none are statistically significant. The lack of a robust positive coefficient for the triple interaction suggests that there is no evidence that potatoes had a larger effect in countries that were more urban at the time of adoption.

Finally, we explore whether the effects of potato adoption differed depending on the ability of the elites to capture the returns of labor. If the increase in agricultural productivity arising from the introduction of potatoes accrued primarily to a small group of elites, rather than to labor more generally, then this may cause potatoes to have a smaller positive impact on aggregate population growth and urbanization. We proxy for the ability of elites to capture the benefits of potatoes

\footnotetext{
${ }^{36}$ It is unclear whether one would also expect a heterogenous effect for population growth. However, for completeness we also report estimates with population and population growth as the dependent variable.
} 
Table 6: Checking for heterogeneous effects of potato adoption.

\begin{tabular}{|c|c|c|c|c|}
\hline & \multicolumn{4}{|c|}{ Dependent variables } \\
\hline & $\begin{array}{c}\text { (1) } \\
\text { In Population }\end{array}$ & $\begin{array}{l}\text { (2) } \\
\text { Population growth }\end{array}$ & $\begin{array}{l}\text { (3) } \\
\text { City population } \\
\text { share }\end{array}$ & $\begin{array}{c}\text { (4) } \\
\text { Change in city } \\
\text { population share }\end{array}$ \\
\hline \multicolumn{5}{|c|}{ Panel A. Differential effects by access to international markets } \\
\hline Potato x Post & $\begin{array}{c}0.710 \\
(0.406)\end{array}$ & $\begin{array}{c}0.691 \\
(0.184)\end{array}$ & $\begin{array}{l}19.545 \\
(6.941)\end{array}$ & $\begin{array}{c}0.151 \\
(0.046)\end{array}$ \\
\hline Potato $\times$ Distance to ice free coast $\times$ Post & $\begin{array}{c}0.0023 \\
(0.0011)\end{array}$ & $\begin{array}{c}0.00038 \\
(0.00040)\end{array}$ & $\begin{array}{l}-0.018 \\
(0.013)\end{array}$ & $\begin{array}{l}-0.00008 \\
(0.00008)\end{array}$ \\
\hline Observations & 922 & 790 & 922 & 790 \\
\hline \multicolumn{5}{|c|}{ Panel B. Differential effects by pre-1700 urbanization } \\
\hline Potato x Post & $\begin{array}{c}1.438 \\
(0.301)\end{array}$ & $\begin{array}{c}0.913 \\
(0.156)\end{array}$ & $\begin{array}{l}18.816 \\
(5.733)\end{array}$ & $\begin{array}{c}0.137 \\
(0.045)\end{array}$ \\
\hline Potato $\times$ City share in $1700 \times$ Post & $\begin{array}{l}-0.027 \\
(0.052)\end{array}$ & $\begin{array}{l}-0.035 \\
(0.022)\end{array}$ & $\begin{array}{l}-1.671 \\
(1.280)\end{array}$ & $\begin{array}{c}0.004 \\
(0.007)\end{array}$ \\
\hline Observations & 922 & 790 & 922 & 790 \\
\hline \multicolumn{5}{|c|}{ Panel C. Differential effects by elite capture, measured by an indicator variable for legal serfdom or domestic slavery in 1700} \\
\hline Potato $\times$ Post & $\begin{array}{c}1.285 \\
(0.297)\end{array}$ & $\begin{array}{c}0.573 \\
(0.159)\end{array}$ & $\begin{array}{c}9.435 \\
(9.482)\end{array}$ & $\begin{array}{c}0.120 \\
(0.049)\end{array}$ \\
\hline Potato $\times$ Serfdom or slavery in $1700 \times$ Post & $\begin{array}{l}-0.139 \\
(0.407)\end{array}$ & $\begin{array}{c}0.302 \\
(0.214)\end{array}$ & $\begin{array}{c}7.953 \\
(10.188)\end{array}$ & $\begin{array}{c}0.020 \\
(0.062)\end{array}$ \\
\hline Observations & 922 & 790 & 922 & 790 \\
\hline
\end{tabular}

with an indicator variable that equals one if there is any evidence from ethnographic and historical sources that either domestic slavery or serfdom was legal in 1700. As above, we then include the interaction of this indicator variable with Potato $_{i} \times I_{t}^{\text {Post }}$ in our estimating equation. A negative coefficient indicates that the benefits of potatoes are greater in regions where the elites are weaker. The estimates, reported in Panel C of Table 6, do not provide evidence of this being the case. Rather than being negative, three of the four coefficients are positive, although none are significant. In sum, we fail to find evidence that the benefits of potatoes systematically vary with the rentcapturing power of the elites. 


\section{Conclusions}

We have estimated the effect of the introduction of the potato on Old World population growth and urbanization. The nutritional and caloric superiority of the potato, and its diffusion from the New World to the Old, allows us to estimate causal effects using a difference-in-differences estimation strategy. According to our most conservative estimates, the introduction of the potato explains $22 \%$ of the observed post-1700 increase in population growth. These results show that food and nutrition matter. By increasing the nutritional carrying capacity of land they can have large effects on population.

To the extent that urbanization serves as a measure of the shift from rural agriculture to urban manufacturing, our estimates also provide historic evidence of the importance of agricultural productivity for economic development. According to our estimates, the introduction of the potato explains $47 \%$ of the post- 1700 increase in the average urbanization rate. Our estimates suggest that increased agricultural productivity can play a significant part in promoting the rise of urban centers, industry, and economic development.

\section{References}

Acemoglu, Daron, Simon Johnson, and James A. Robinson, "Reversal of Fortune: Geography and Institutions in the Making of the Modern World Income Distribution," Quarterly Journal of Economics, 117 (2002), 1231-1294.

- "The Rise of Europe: Atlantic Trade, Institutional Change and Economic Growth," American Economic Review, 95 (2005), 546-579.

Bairoch, Paul, Cities and Economic Development: From the Dawn of History to the Present (University of Chicago Press, Chicago, 1988).

Baten, Jörg, and John E. Murray, "Heights of Men and Women in 19th-Century Bavaria: Economic, Nutritional, and Disease Influences," Explorations in Economic History, 37 (2000), 351-369.

Blayo, Yves, “La Mortalité en France de 1740 a 1829," Population (French Edition), 30 (1975), 123-142.

Burkill, I.H., A Dictionary of the Economic Products of the Malay Peninsula (Crown Agents for the Colonies, London, 1935).

Chandler, Tertius, Four Thousand Years of Urban Growth: An Historical Census (The Edwin Meller Press, Lewiston, U.S.A., 1987).

Connell, K.H., “The History of the Potato," Economic History Review, 3 (1951), 388-395.

— " "The Potato in Ireland," Past and Present, 23 (1962), 57-71.

Cullen, L.M., "Irish History Without the Potato," Past and Present, 40 (1968), 72-83. 
Cutler, David M., Your Money or Your Life (Oxford University Press, New York, 2004).

Cutler, David M., Angus Deaton, and Adriana Lleras-Muney, "The Role of Public Health Improvements in Health Advances: The Twentieth-Century United States," Demography, 42 (2005), 1-22.

_ , "The Determinants of Mortality," Journal of Economic Perspectives, 20 (2006), 97-120.

Davidson, Stanley, and R. Passmore, Human Nutrition and Dietetics (Churchill Livingstone, Baltimore, 1965).

Davidson, Stanley, R. Passmore, J.F. Brock, and A.S. Truswell, Human Nutrition and Dietetics (Churchill Livingstone, New York, 1975).

DeLong, J. Bradford, and Andrei Shleifer, "Princes and Merchants: City Growth Before the Industrial Revolution," Journal of Law and Economics, 36 (1993), 671-702.

Donaldson, Dave, "Railroads of the Raj: Estimating the Impact of Transportation Infrastructure," (2008), mimeo, London School of Economics.

Fogel, Robert W., "Nutrition and the Decline in Mortality since 1700: Some Preliminary Findings," Working Paper 1402, NBER (1984).

- "Economic Growth, Population Theory, and Physiology: The Bearing of Long-Term Processes on the Making of Economic Policy," American Economic Review, 84 (1994), 369-395.

-, "New Findings on Secular Trends in Nutrition and Mortality: Some Implications for Population Theory," in Mark R. Rosenzweig and Oded Stark, eds., Handbook of Population and Family Economics (Elsevier Science, North Holland, Charlottesville, 1997), 433Ü-481.

- The Escape from Hunger and Premature Death, 1700-2100 (Cambridge University Press, New York, 2004).

Galor, Oded, and David N. Weil, "Population, Technology and Growth: From Malthusian Stagnation to the Demographic Transition and Beyond," American Economic Review, 90 (2000), 806-828.

Hather, Jon, and Patrick V. Kirch, "Prehistoric Sweet Potato (Ipomoea Batatas) from Mangaia Island, Central Polynesia," Antiquity, 65 (1991), 887-893.

Hughes, R.E., "Scurvy," in Kenneth F. Kiple, ed., The Cambridge World History of Food, Volume II (Cambridge University Press, New York, 2000), 988-1000.

Ingram, John Kells, A History of Slavery and Serfdom (Adam and Charles Black, London, 1895).

Jones, Charles, "Population and Ideas: A Theory of Endogenous Growth," in Philippe Aghion, Roman Frydman, Joseph Stiglitz, and Michael Woodford, eds., Knowledge, Information, and Expectations in Modern Macroeconomics: In Honor of Edmund S. Phelps (Princeton University Press, Princeton, 2003), 498-521.

Jones, Eric L., The European Miracle: Environments, Economies, and Geopolitics in the History of Europe and Asia (Cambridge University Press, New York, 1981).

Landes, David S., The Wealth and Poverty of Nations: Why Some are so Rich and Some so Poor (W.W. Norton \& Company, New York, 1998).

Langer, William L., “Europe's Initial Population Explosion,” American Historical Review, 69 (1963), $1-17$. 
—, An Encyclopedia of World History, Fifth Edition (Houghton Mifflin Company, Boston, 1972).

—, "American Foods and Europe's Population Growth," Journal of Social History, 8 (1975), $51-66$.

Lee, James, "Food Supply and Population Growth in Southwest China, 1250-1850," Journal of Asian Studies, 41 (1982), 711-746.

Livi-Bacci, Massimo, Population and Nutrition: An Essay on European Demographic History (Cambridge University Press, Cambridge, 1991).

Maddison, Angus, Dynamic Forces in Capitalist Development (Oxford University Press, Oxford, 1991).

, The World Economy: A Millenia Perspective (Organisation for Economic Co-operation and Development, Paris, 2001).

- The World Economy: Historical Statistics (Organisation for Economic Co-operation and Development, Paris, 2003).

McEvedy, Colin, and Richard Jones, Atlas of World Population History (Penguin Books, New York, 1978).

McKeown, Thomas, The Modern Rise of Population (Academic Press, New York, 1976).

McNeill, Wiliam H., "The Introduction of the Potato into Ireland," Journal of Modern History, 21.

—_ "How the Potato Changed the World's History," Social Research, 66 (1999), 67-83.

Messer, Ellen, "Maize," in Kenneth F. Kiple and Kriemhild Coneè Ornelas, eds., The Cambridge History of World Food, Volume I (Cambridge University Press, New York, 2000a), 97-112.

—, "Potatoes," in Kenneth F. Kiple and Kriemhild Coneè Ornelas, eds., The Cambridge History of World Food, Volume I (Cambridge University Press, New York, 2000b), 187-201.

Mitchell, B.R., International Historical Statistics: Africa, Asia and Oceania, 1750-1993 (Palgrave MacMillan, London, 1998).

—, International Historical Statistics: Europe (Palgrave MacMillan, London, 2003).

Modelski, George, World Cities: -3000 to 2000 (Faros, Washington, D.C., 2003).

Mokyr, Joel, "Irish History with the Potato," Irish Economic and Social History, 8 (1981), 8-29.

Murdock, George Peter, Ethnographic Atlas (University of Pittsburgh Press, Pittsburgh, 1967).

Nunn, Nathan, "The Long-Term Effects of Africa's Slave Trades," Quarterly Journal of Economics, 123 (2008), 139-176.

Nunn, Nathan, and Diego Puga, "Ruggedness: The Blessing of Bad Geography in Africa," (2007), mimeo.

O'Brien, Patricia J., "Sweet Potatoes and Yams," in Kenneth F. Kiple and Kriemhild Coneè Ornelas, eds., The Cambridge History of World Food, Volume I (Cambridge University Press, New York, 2000), 207-218. 
Pandey, S.K., and S.K. Kaushik, "Origin, Evolution, History and Spread of Potato," in S.M. Paul Khurana, J.S. Minhas, and S.K. Pandey, eds., The Potato: Production and Utilization in Sub-Tropics (Mehta, New Delhi, 2003).

Parker, Geoffrey, Cambridge Illustrated History of Warfare (Cambridge University Press, London, 2000).

Preston, Samuel H., "The Changing Relation Between Mortality and Level of Economic Development," Population Studies, 29 (1975), 231-248.

- "Causes and Consequences of Mortality Declines in Less Developed Countries during the 20th Century," in Richard A. Easterlin, ed., Population and Economic Change in Developing Countries (University of Chicago Press, Chicago, 1980), 289-360.

—, "American Longevity: Past, Present, and Future," (1996), mimeo, Syracuse University.

Reader, John, Propitious Esculent: The Potato in World History (William Heinemann, London, 2008).

Russell, J.C., British Medieval Population (University of New Mexico, Albuquerque, 1948).

Salaman, Redcliffe, The History and Social Influence of the Potato (Cambridge University Press, Cambridge, 1949).

Stearns, Peter, The Industrial Revolution in World History, Third Edition (Westview Press, Boulder, Colorado, 2007).

Tiffin, Richard, and Xavier Irz, "Is Agriculture the Engine of Growth?" Agricultural Economics, 35 (2006), 79-89.

Timmer, Peter, "The Turnip, the New Husbandry, and the English Agricultural Revolution," Quarterly Journal of Economics, 83 (1969), 375-395.

U.S. Department of Agriculture, USDA National Nutrient Database for Standard Reference, Release 20 (U.S. Department of Agriculture, Agricultural Research Service, Washington, D.C., 2007).

Voigtländer, Nico, and Hans-Joachim Voth, "Why England? Demographic Factors, Structural Change and Physical Capital Accumulation during the Industrial Revolution," Journal of Economic Growth, 11 (2006), 319-361.

Wrigley, E.A., R.S. Davies, J.E. Oeppen, and R.S. Schofield, English Population History from Family Reconstitution, 1580-1837 (Cambridge University Press, Cambridge, 1997).

Young, Arthur, The Farmer's Tour through the East of England, Volume 4 (W. Strahan, London, 1771).

\section{A. Data Appendix}

\section{Crop suitability measures}

Data on the suitability of climates for growing different crops are from the FAO's Global AgroEcological Zones (GAEZ) 2000 database (http://fao.org/Ag/AGL/agll/gaez/index.htm). We use the country level measures that have constructed by the FAO for our country-level regressions. 
We construct a measure of the average suitability of each country's neighbors by first identifying, for each country, all countries that share a border. We then construct an average measure of suitability, weighted by land area. For islands, their neighbor is effectively the ocean, where one cannot cultivate potatoes. We therefore assign zero suitability for islands. All results using the neighbors' potato suitability measure are completely robust to simply omitting islands from the analysis.

\section{Population and urbanization}

Country level population data are from McEvedy and Jones (1978). Data on the populations of cities with more than 20,000 inhabitants are from Chandler (1987), Bairoch (1988), and Modelski (2003).

\section{Geographic characteristics}

A country's average elevation, average ruggedness, and average distance from an ice-free coast are taken from Nunn and Puga (2007). A country's average elevation is measured in meters. Ruggedness is the average uphill slope of a country's land area. A country's average distance from an ice-free coast is measured in kilometers. See Nunn and Puga (2007) for details of measurement and the underlying data sources.

\section{Other control variables}

The number of slaves taken from a country during the Indian Ocean, Red Sea, trans-Saharan, and trans-Atlantic slave trades each century from 1400 to 1900 is taken from Nunn (2008). Our control variable for slave exports is the natural log of the number of slaves exported (measured in millions of people). When we take the natural $\log$, countries with zero slaves exported are treated as exporting one slave.

Our control for a history of Roman rule is an indicator variable that equals one if a country was a part of the Roman Empire. This measure is taken from Acemoglu et al. (2005).

We construct an indicator variable that equals one if there is evidence of either legal serfdom or domestic slavery in a country in 1700. For information on the prevalence of domestic slavery we rely on data from George Peter Murdock's (1967) Ethnographic Atlas. Using the location data provided for the 1,267 ethnic groups in the Atlas, we match each ethnic group to a modern country. 
We then construct an indicator variable if there is evidence that any of the ethnic groups have domestic slavery, whether it is hereditary or otherwise. We also assign a value of one to the variable if there is evidence of serfdom in 1700. This information is from Ingram (1895).

\section{City-level variables}

Data on the populations of cities with more than 20,000 inhabitants are from Chandler (1987), Bairoch (1988) and Modelski (2003). The locations of cities were identified using the global gazetteer Geonames, which is accessible at: www.geonames . org.

Data on the suitability of the climate of a city for growing various crops are from the FAO's Global Agro-Ecological Zones (GAEZ) 2002 database. The data are publicly available and can be downloaded from: http://www.iiasa.ac.at/Research/LUC/SAEZ/index.html. We use their underlying grid-cell data, which are available as GIS raster files. City level suitability is defined as the suitability of grid-cells within a 100 kilometer radius of the city.

The underlying data used to construct city-level measures of ruggedness are from the FAO's Terrastat 2002 data compilation. The data are originally from the USGS GPOTO 30 elevation grid,

which is the same source used by Nunn and Puga (2007) to construct a country-level measure of terrain ruggedness. Ruggedness is measured as the average uphill slope of land within a 100 kilometer radius of the city. Data used to construct each city's average elevation (measured in meters) is from Global Mapping International's Seamless Digital Chart of the World Base Map (DCW), version 3.2. 
Table A1: Correlations with potato suitability.

\begin{tabular}{|c|c|c|}
\hline & & Potato suitability \\
\hline \multirow{4}{*}{ 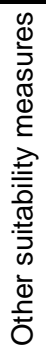 } & Neighbors' potato suitability & 0.661 \\
\hline & All crops suitability & 0.577 \\
\hline & Old World staple crops suitability & 0.712 \\
\hline & New World staple crops suitability & 0.601 \\
\hline \multirow{2}{*}{$\begin{array}{l}\text { ते } \\
\frac{0}{0} \\
\frac{0}{0} \\
\mathbb{d} \\
0\end{array}$} & Average elevation & -0.216 \\
\hline & Average ruggedness & -0.058 \\
\hline
\end{tabular}

Notes: The table reports pairwise correlation coefficients for the 132

Old World countries in the sample.

Table A2: Summary statistics.

\begin{tabular}{|c|c|c|c|c|c|c|}
\hline & \multicolumn{3}{|c|}{ Country level data } & \multicolumn{3}{|c|}{ City level data } \\
\hline & Obs & Mean & Std. error & Obs & Mean & Std. error \\
\hline \multicolumn{7}{|l|}{ A. Demographic variables } \\
\hline In Population & 922 & -0.265 & $(1.808)$ & 885 & -2.669 & $(0.920)$ \\
\hline Population growth & 790 & 0.231 & $(0.272)$ & 649 & 0.331 & $(0.650)$ \\
\hline City population share & 922 & 2.794 & $(0.593)$ & & & \\
\hline Change in city population share & 790 & 0.007 & $(0.049)$ & & & \\
\hline \multicolumn{7}{|l|}{ B. Agricultural suitability variables } \\
\hline Potato suitability & 922 & 0.078 & $(0.144)$ & 885 & 0.278 & $(0.292)$ \\
\hline All crops suitability & 922 & 0.290 & $(0.236)$ & 885 & 0.636 & $(0.300)$ \\
\hline Old World staple crops suitability & 922 & 0.211 & $(0.206)$ & 885 & 0.433 & $(0.316)$ \\
\hline New World staple crops suitability & 922 & 0.170 & $(0.175)$ & 885 & 0.362 & $(0.292)$ \\
\hline Neighbors' potato suitability & 922 & 0.063 & $(0.106)$ & & & \\
\hline \multicolumn{7}{|l|}{ C. Geography variables } \\
\hline Average elevation & 922 & 613.130 & $(563.060)$ & 885 & 812.851 & $(0.708)$ \\
\hline Average ruggedness & 922 & 3.404 & $(0.329)$ & 885 & 15.908 & $(0.990)$ \\
\hline Average distance from ice-free coast & 922 & 380.556 & $(431.544)$ & & & \\
\hline \multicolumn{7}{|l|}{ D. Other variables } \\
\hline Existence of serfdom or slavery in 1700 & 922 & 0.161 & $(0.350)$ & & & \\
\hline City population share in 1700 & 922 & 2.229 & $(0.410)$ & & & \\
\hline Population growth $1000-1400$ & 922 & 0.098 & $(0.078)$ & & & \\
\hline Part of the Roman Empire & 922 & 0.061 & $(0.239)$ & & & \\
\hline In Total slave exports & 922 & -14.294 & $(4.332)$ & & & \\
\hline
\end{tabular}


Table A3: Flexible equation estimates for potato suitability and all crops suitability.

\begin{tabular}{|c|c|c|c|c|}
\hline & \multicolumn{4}{|c|}{ Dependent Variable } \\
\hline & $\begin{array}{c}\text { (1) } \\
\text { In Population }\end{array}$ & $\begin{array}{c}\text { (2) } \\
\text { Population growth }\end{array}$ & $\begin{array}{c}(3) \\
\text { City population } \\
\text { share }\end{array}$ & $\begin{array}{c}(4) \\
\text { Change in city } \\
\text { population share }\end{array}$ \\
\hline \multirow[t]{2}{*}{ Potato $\times 1400$} & 0.261 & & 10.960 & \\
\hline & $(0.157)$ & & (8.371) & \\
\hline \multirow[t]{2}{*}{ Potato x 1500} & 0.437 & 0.117 & 5.118 & -0.085 \\
\hline & $(0.230)$ & $(0.065)$ & (2.994) & $(0.083)$ \\
\hline \multirow[t]{2}{*}{ Potato x 1600} & 0.573 & 0.076 & 1.118 & -0.067 \\
\hline & $(0.235)$ & $(0.079)$ & $(4.893)$ & $(0.034)$ \\
\hline \multirow[t]{2}{*}{ Potato $\times 1700$} & 0.497 & -0.135 & 3.941 & 0.001 \\
\hline & $(0.268)$ & $(0.073)$ & (3.286) & $(0.044)$ \\
\hline \multirow[t]{2}{*}{ Potato x 1800} & 1.293 & 0.737 & 5.123 & -0.015 \\
\hline & $(0.334)$ & $(0.106)$ & (2.903) & $(0.043)$ \\
\hline \multirow[t]{2}{*}{ Potato x 1900} & 2.380 & 1.027 & 32.484 & 0.247 \\
\hline & $(0.414)$ & $(0.117)$ & (5.927) & $(0.058)$ \\
\hline \multirow[t]{2}{*}{ All Crops x 1400} & 0.522 & & 0.555 & \\
\hline & $(0.117)$ & & $(1.654)$ & \\
\hline \multirow[t]{2}{*}{ All Crops x 1500} & 0.653 & 0.030 & 0.567 & 0.000 \\
\hline & $(0.138)$ & $(0.027)$ & $(1.696)$ & $(0.013)$ \\
\hline \multirow[t]{2}{*}{ All Crops x 1600} & 0.626 & -0.128 & 3.861 & 0.033 \\
\hline & $(0.131)$ & $(0.067)$ & (2.698) & $(0.020)$ \\
\hline \multirow[t]{2}{*}{ All Crops x 1700} & 0.826 & 0.098 & 1.801 & -0.021 \\
\hline & $(0.158)$ & $(0.051)$ & $(1.751)$ & $(0.021)$ \\
\hline \multirow[t]{2}{*}{ All Crops x 1800} & 0.792 & -0.135 & 1.055 & -0.008 \\
\hline & (0.191) & $(0.055)$ & $(1.756)$ & $(0.012)$ \\
\hline \multirow[t]{2}{*}{ All Crops x 1900} & 0.567 & -0.327 & -3.398 & -0.045 \\
\hline & $(0.255)$ & $(0.125)$ & $(2.529)$ & $(0.019)$ \\
\hline F-test for Potato $\times 1800=$ Potato $\times 1900=0$ & 34.44 & 50.56 & 16.93 & 19.35 \\
\hline Observations & 922 & 790 & 922 & 790 \\
\hline
\end{tabular}

